\title{
YKL-40 - A Protein in the Field of Translational Medicine: A Role as a Biomarker in Cancer Patients?
}

\author{
Nicolai A. Schultz ${ }^{1}$ and Julia S. Johansen ${ }^{2,3, *}$
}

1 Departments of Surgical Gastroenterology, Herlev Hospital, University of Copenhagen, Herlev Ringvej 75, DK-2730 Herlev, Denmark; E-Mail: nicolai-schultz@dadlnet.dk

Departments of Oncology, Herlev Hospital, University of Copenhagen, Herlev Ringvej 75, DK-2730 Herlev, Denmark

3 Departments of Medicine, Herlev Hospital, University of Copenhagen, Herlev Ringvej 75, DK-2730 Herlev, Denmark

* Author to whom correspondence should be addressed; E-Mail: julia.johansen@post3.tele.dk; Tel.: 45-44884488 ext. 89241; Fax: 45-44884214.

Received: 13 May 2010; in revised form: 1 July 2010 / Accepted: 9 July 2010 /

Published: 12 July 2010

\begin{abstract}
YKL-40 is a $40 \mathrm{kDa}$ glycoprotein produced by cancer cells, inflammatory cells and stem cells. It probably has a role in cell proliferation and differentiation, inflammation, protection against apoptosis, stimulation of angiogenesis, and regulation of extracellular tissue remodelling. Plasma levels of YKL-40 are often elevated in patients with localized or advanced cancer compared to age-matched healthy subjects. Several studies have demonstrated that high plasma YKL-40 is an independent prognostic biomarker of short survival in patients with different types of cancer. However, there is not yet sufficient data to support determination of plasma YKL-40 outside research projects as a biomarker for screening of gastrointestinal cancer and determination of treatment response and poor prognosis before or during treatment and follow-up. Plasma YKL-40 is also elevated in patients with other diseases than cancer, e.g., severe infections, cardiovascular disease, diabetes, chronic obstructive lung disease, asthma, liver fibrosis and rheumatoid arthritis. Co-morbidity should therefore always be considered in patients with cancer, since other sources than cancer cells can increase plasma YKL-40 levels. Future focused translational research projects combining basic and clinical research are needed in a joint effort to answer questions of the complex function and regulation of YKL-40 and the question if plasma YKL-40 is a clinical useful biomarker in patients with cancer.
\end{abstract}


Keywords: biomarker; cancer; CHI3L1; inflammation; YKL-40; tissue remodelling

\section{Introduction}

A critical step in translational medicine for personalizing treatment is to identify new diagnostic, prognostic and predictive cancer biomarkers. There has therefore been an increasing focus on identification of novel cancer biomarkers. Tumor molecular profiling is now included in many clinical trials [1]. New biomarkers have the potential to identify cancer patients at an early stage, select patients who are most likely to benefit from therapy and to guide the development of more effective agents. New biomarkers will help to personalize standard medicine for patients with cancer.

Tumor molecular heterogeneity is a major reason that patients with cancer with a similar tumor histology and clinical stage can have a very different clinical outcome and response to treatment with chemotherapy and biologics (e.g., antibodies against the epidermal growth factor receptors and insulin growth factor receptor). A new generation of molecular technologies, including genomic, proteomic and metabolomic mapping, holds the promise of translating into practice the use of biomarker panels for increased diagnostic and therapeutic sensitivity and specificity.

A protein biomarker is, in general defined, as a measurable protein that is an indicator of normal biologic processes, pathogenic processes, and/or response to therapeutic or other interventions. The definition does not include specific technologies except that the biomarker should be possible to measure objectively [2] (http://www.fda.gov/cder/guidance/6400fnl.htm/, September 2004). Protein cancer biomarkers should have an association with cancer and an application in clinical detection (screening and early diagnosis) and management (prognosis, treatment response and monitoring). Prognostic biomarkers can forecast survival independent of the treatment administered. Predictive biomarkers should identify cancer patients who are likely to have increased sensitivity or resistance to a given therapy reflected in either tumor shrinkage or growth and prolonged survival or decreased survival. Biomarkers can be both prognostic and predictive. It is most likely that biomarkers should be combined in panels of biomarkers for optimal clinical use, since most biomarkers will probably individually lack optimal sensitivity and specificity. This review focuses on plasma YKL-40 as a potential new cancer biomarker.

\section{YKL-40 Gene and Protein}

In 1997, the human gene encoding the protein YKL-40 was isolated [3]. It is located on chromosome 1q32.1, has a size of 7948 base pairs and consists of 10 exons [3,4]. Two splice forms of the YKL-40 gene are reported; isoform 1 contains exon 1-10 and in isoform 2 exon 8 is spliced out [5].

YKL-40 [6] is also named human cartilage glycoprotein-39 (HC-gp39) [7], 38-kDa heparin-binding glycoprotein (gp38k) [8], chitinase-3-like-1 (CHI3L1) [3], and chondrex [9]. It is a glycoprotein and a member of "Family 18 chitolectins" [10-12] and "Mammalian chitinase like proteins". YKL-40 is described in human [7], chimpanzee, pig [8], cow, goat [13], sheep, guinea pig [14], rat and mouse [15] and is phylogenetically highly conserved. The fruit fly Drosophila melanogaster [16,17], the mosquito Anopheles gambiae, the zebra fish Danio rerio, the pacific oyster Crassostrea gigas [18] and the nematode 
Caenorhabditis elegans have putative YKL-40-like proteins (National Center for Biotechnology Information (NCBI)). The YKL-40 protein contains a single polypeptide chain of 383 amino acids and has a molecular mass of $40 \mathrm{kDa}$ [7] and an isoelectric point of 7.6 [19]. The crystallographic structure for human YKL-40 [20,21] displays the typical fold of family 18 glycosyl hydrolases [22].

\section{YKL-40 in Healthy Subjects}

\subsection{Tissue}

We have found that YKL-40 is produced by human embryonic stem cells and their progenitors, Figure 1A-C [23]. YKL-40 mRNA and protein expressions are also strongly expressed in all germ layers of human embryos and in human fetal tissues of ecto-, meso- and endoderm layers [5]. At the cellular level YKL-40 protein expression is high in embryonic and fetal tissues characterized by rapid proliferation and marked differentiation, and in tissues undergoing morphogenetic changes [5]. In adult normal tissue high YKL-40 expression is observed in cells with high cellular activity [24].

Figure 1. YKL-40 protein expression determined by immunohistochemical analysis in cultures of human embryonic stem cells (A) and in a biopsy of human embryonal carcinoma (D). Membrane staining of the region enclosed by square labelled B in A (B) or strong cytoplasmatic staining are seen in embryonic stem cells in vitro (C) and in embryonal carcinoma cells in vivo (D).

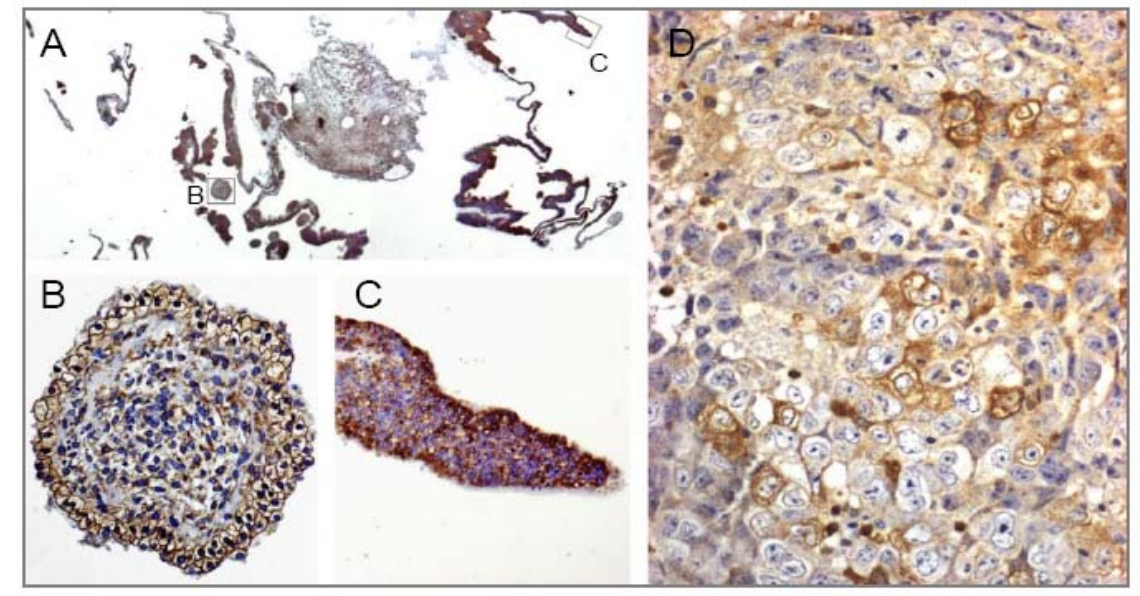

\subsection{Plasma Concentrations of YKL-40 in Healthy Subjects}

To be clinically useful determination of plasma YKL-40 must use specific, sensitive, cheap and fast methods allowing reliable measurements, optimal capability for high throughput tests, prompt turnaround time, and reasonable cost. The most used commercial enzyme-linked immunoassay (ELISA) to determine plasma YKL-40 is from Quidel (Santa Clara, CA, USA) [9]. It uses streptavidincoated microplate wells, a biotinylated-Fab monoclonal mouse antibody against human YKL-40 (capture antibody) and an alkaline phosphatase-labeled polyclonal rabbit antibody against human YKL-40 (detection antibody). The sensitivity is $20 \mu \mathrm{g} / \mathrm{L}$, detection limit $8 \mu \mathrm{g} / \mathrm{L}$, and recovery 102\%. The intra-assay coefficients of variations are 5\% (at $40 \mu \mathrm{g} / \mathrm{L}$ ), 4\% (at $104 \mu \mathrm{g} / \mathrm{L}$ ), and 4\% (at $155 \mu \mathrm{g} / \mathrm{L}$ ). The inter-assay coefficient of variation is $<6 \%$ (personal observations). An ELISA from R\&D Systems 
(Abingdon, Oxon, United Kingdom) is also become commercial available, but there are no publications regarding this ELISA.

Plasma levels of YKL-40 in both sexes are highly ( $p$ 0.001) correlated with age [9,25-27]. Thus, the normal, age-corrected, upper level of plasma YKL-40 is an important factor to consider in clinical studies of patients with cancer using plasma YKL-40 as a potential biomarker. There is no difference in plasma YKL-40 between the two sexes and the median plasma YKL-40 level in healthy subjects is $\sim 40 \mu \mathrm{g} / \mathrm{L}[9,25,26]$. In these three studies used to determine the normal plasma YKL-40 levels, there were no follow-up of the subjects after the blood samples were collected for plasma YKL-40 determination. This is an important problem, since it has been reported that plasma YKL-40 can be elevated years before a subject has clinical signs of cancer [27]. We have therefore determined plasma YKL-40 in a large group of 3610 healthy adults, aged 20-95 years, from the Danish general population, the Copenhagen City Heart Study. These subjects had no known disease at time of blood sampling in 1991-1994 and remained healthy during the 16 years follow-up period (Bojesen, S.E., manuscript in preparation). We found that plasma YKL-40 increased significantly with age in both sexes, and was not associated with body mass index (BMI) and plasma C-reactive protein (CRP) levels. Furthermore, plasma YKL-40 was stable in subjects that remain healthy during a 10 years period. Based on the results from this large study of truly healthy subjects we suggest that an elevated plasma YKL-40 is defined as an age-corrected plasma YKL-40 concentration higher than the $95^{\text {th }}$ or the $97^{\text {th }}$ percentile of plasma YKL-40 in healthy age-matched subjects.

Recently, a new technique to determine plasma YKL-40 has been developed using the proximity ligation assay (PLA) [28,29]. This method employs pairs of antibodies coupled to DNA oligonucleotides such that when the antibody pairs bind to the target protein, the local concentration of DNA oligonucleotides increases to allow for enzymatic ligation of the two strands. The resulting amplicons are unique for each specific protein detected and can be measured in a highly quantitative manner by real-time quantitative real time polymerase chain reaction (qPCR). The PLA technique can be multiplexed for simultaneous detection of multiple proteins, is highly sensitive with limited background, and requires only $10 \mu \mathrm{L}$ of plasma. This technology has been piloted in small scale biomarker studies where YKL-40 is one of 83 biomarkers [28,29]. However, more validation studies are needed and this multiplex PLA system is not yet commercially available.

A standard operating procedure must be used when handling blood samples for determination of plasma YKL-40. The time interval between drawing of blood and centrifugation of blood stored at room temperature must be less than eight hours for EDTA plasma samples and less than three hours for serum. Otherwise, significant and non-disease related elevations in plasma YKL-40 are found. If the blood is stored at $4{ }^{\circ} \mathrm{C}$ before centrifugation YKL-40 concentrations are stable in EDTA plasma for 72 hours and in serum for 24 hours [30]. Degranulation of neutrophils will release YKL-40 from the specific granules, and neutrophils are the main source of this time dependent increase in YKL-40 concentrations in serum and EDTA plasma. After the blood cells are removed, YKL-40 is stable in plasma stored up to five days at room temperature [30], up to nine days at $4{ }^{\circ} \mathrm{C}$ [9], and at $-80{ }^{\circ} \mathrm{C}$ for at least 14 years (personal observation). Repetitive freezing and thawing of plasma samples up to nine times have no effect on plasma YKL-40 levels [9,30,31]. The YKL-40 serum/EDTA plasma ratio is 1.4, and the YKL-40 levels in corresponding serum and EDTA plasma samples are correlated (rho $=0.98, \mathrm{p}<0.001)[30,31]$. The slightly higher levels of YKL-40 in serum compared to EDTA 
plasma is probably caused by release of YKL-40 from activated neutrophils during the coagulation process. In this review, there will be no discrimination between YKL-40 levels in EDTA plasma and serum samples, since the levels of YKL-40 in the patients were related to EDTA plasma or serum concentrations of YKL-40 in healthy subjects.

Plasma YKL-40 levels are relatively stable in healthy subjects during a day, a month, a year and during a period of three years. The within subject coefficient of variations including variation over time and inter-assay were $28.8 \%$ and $30.2 \%$ over a period of two and three years, and the intra-class correlation coefficients were $72.4 \%$ and $72.2 \%$ indicating reasonable reliability of plasma YKL-40 measurements. An estimated variation in plasma YKL-40 within healthy subjects including inter-assay variation suggests that an increase of more than $109 \%$ or a decrease of more than $52 \%$ in plasma YKL-40 could be considered as significant and not only a reflection of pre-analytical conditions, methodological and normal biologic variability [26]. Furthermore, plasma YKL-40 was stable in 929 healthy subjects from the Danish general population, who had plasma YKL-40 measured twice in blood samples collected with 10 years interval (Bojesen, S.E., manuscript in preparation).

\section{YKL-40 in Different Types of Cancer}

The pivotal criterion with regard to the potential clinical value of a candidate cancer biomarker is the consistency and strenght of the association between the biomarker and the outcome of the cancer of interest, and the extent to which it is an improvement on either adding to or replacing established tools. The use of plasma YKL-40 has not received Food and Drug Administration (FDA) approval for use as a biomarker in patients with cancer. It is not known whether determination of plasma YKL-40 can be useful in clinical practice, e.g., allowing clinicians to use elevated plasma YKL-40 in risk assessment of healthy subjects and patients, in treatment selection and in monitoring disease relapse or progression during and after treatment.

In the next sections we will describe what has been published since the first publication 15 years ago describing plasma YKL-40 as a potential marker of prognosis in patients with recurrent breast cancer [32]. In the beginning there was little interest in plasma YKL-40 as a biomarker, but during the last few years the number of publications regarding YKL-40 has increased markedly (Figure 2).

Figure 2. The number of publications each year regarding YKL-40.

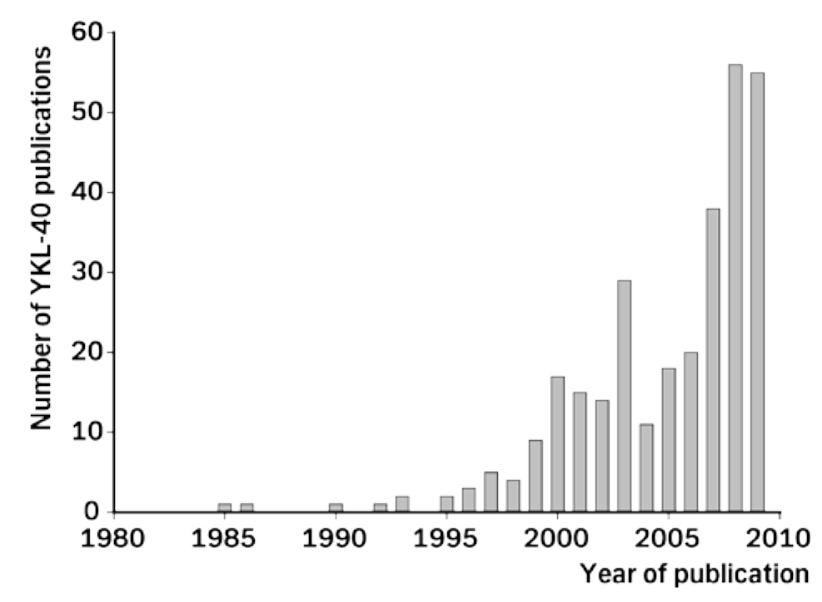




\subsection{Adenocarcinoma}

\subsubsection{Tissue}

Figure 3. YKL-40 protein expression determined by immunohistochemical analysis in biopsies from patients with different types of cancer. (A) Normal breast epithelium with weak YKL-40 staining and strong staning in inflammatory cells; (B) Invasive ductal carcinoma of the breast with strong, diffuse cytoplasmic staining; (C) Colorectal carcinoma with strong, diffuse cytoplasmic staining; (D) Ovarian carcinoma with moderate, cytoplasmic staining; (E) Squamous cell carcinoma of the head and neck with strong, diffuse cytoplasmic staining; (F) Squamous cell carcinoma of the cervix with strong, diffuse cytoplasmic staining; (G) Melanoma with strong, diffuse cytoplasmic staining; $(\mathrm{H})$ Hepatocellular carcinoma with low cytoplasmic staining (large arrows) and a bile duct with dot-like staining (in Golgi) of normal epithelial cells (small arrows); and (I) Pancreatic carcinoma with strong, diffuse cytoplasmic staining (large arrows) and low staining in normal epithelial cells (small arrows).

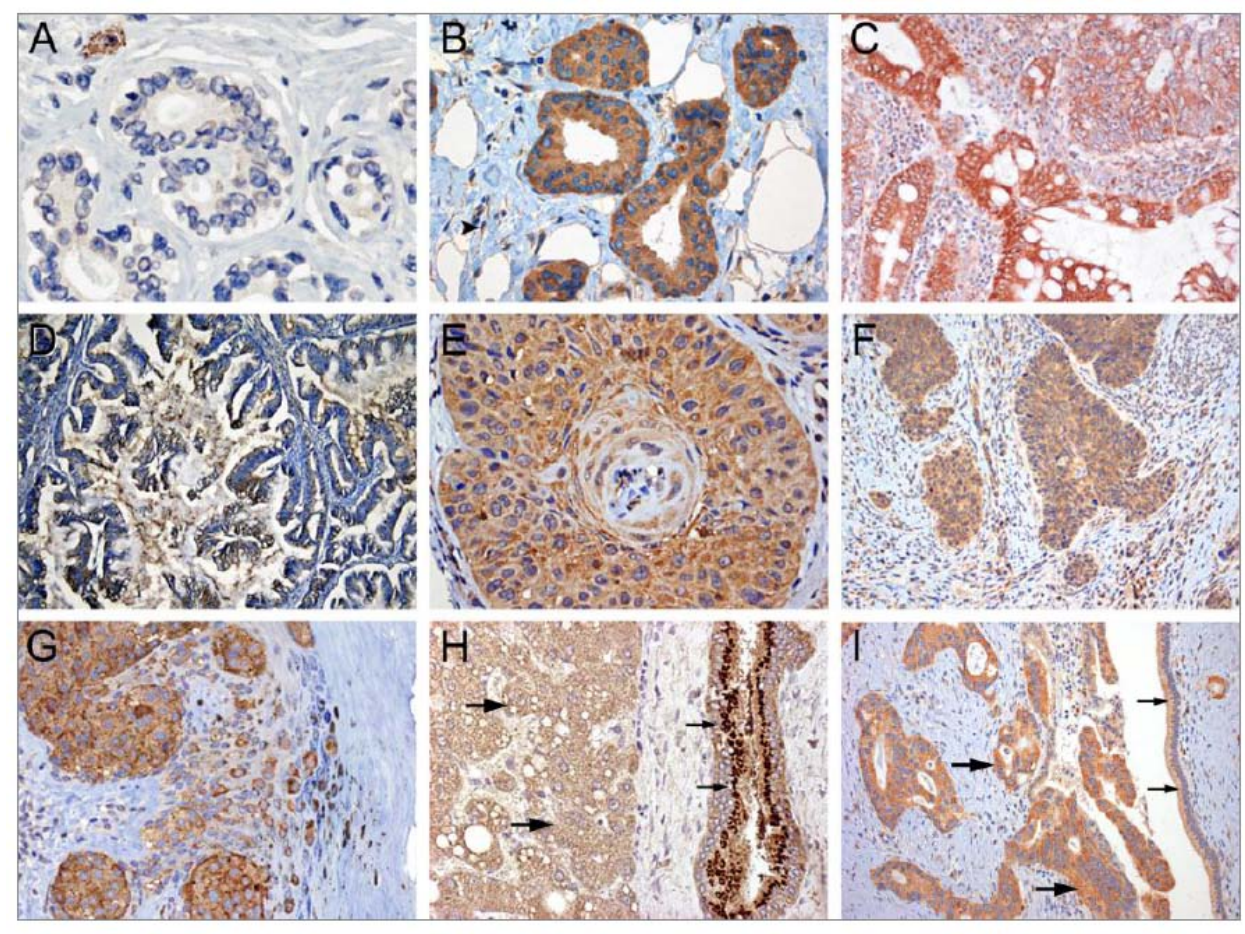

YKL-40 mRNA and protein expression are found in cancer tissue from breast, colon, liver, lung, ovary, pancreas, prostate, gastric and uterus [33], and in tumor associated macrophages [33-38], Figure 3 B,C,D,H,I. There are no reports of adenocarcinoma cell lines producing high levels of YKL-40 in vitro. This is in contrast to the very high YKL-40 production in vitro by the human osteosarcoma cell line MG63 [6]. Microarray gene analyses have shown that YKL-40 is overexpressed compared to normal tissue in human papillary thyroid carcinoma [39]. In breast cancer YKL-40 protein expression is high compared to normal breast tissue Figure 3A, B [40-43] and was a predictor of short disease-free survival in a small study [40]. However, this could not be confirmed in a large study of patients with primary breast cancer [43]. In colorectal, gastric, hepatocellular, pancreatic, 
non-small cell lung and ovarian adenocarcinoma YKL-40 protein expression is high compared to normal tissues [36-38,44] as illustrated in Figure 3C, D, H, I. In colorectal cancer (personal observation), non-small cell lung cancer [37], and ovarian cancer [36] the YKL-40 protein expression scores were not associated with prognosis. Whereas in gastric cancer high YKL-40 protein expression was an independent biomarker of short survival and associated with tumor invasion, lymph node metastasis and activation of Akt [38].

\subsubsection{Screening}

Plasma YKL-40 has been determined in a large prospective cohort study of 8899 subjects (aged 20-95 years) from the Danish general population, the Copenhagen City Heart Study, followed for 11 years for cancer incidence and for 14 years for death. Very high plasma YKL-40 levels, i.e., in the 96-100\% percentile category, in subjects without known cancer predicted a 3.4 fold increased risk of gastrointestinal cancer (multifactorially adjusted for sex, age, smoking history, alcohol intake, and body mass index). Furthermore, high plasma YKL-40 levels predicted an absolute 10-year risk of gastrointestinal cancer of $14 \%$ in women and $20 \%$ in men and who were $>70$ years and smokers [27]. Mechanistically, this increased risk of gastrointestinal cancer may be explained either by the fact that cancer cells and tumor associated macrophages produce YKL-40, that elevated YKL-40 cause gastrointestinal cancer, or that a common factor like chronic inflammation cause both elevated plasma YKL-40 and cancer. An association between a biomarker and a disease may represent a causal relationship (causation), an increase in the biomarker as a consequence of the disease or its treatment (reverse causation), or an association that is spurious because both the biomarker and the disease are affected independently by another known or unknown factor (confounding) [45]. Studies are ongoing in relation to YKL-40 genotyping in this large cohort of 8899 subjects and we want to test the following hypotheses: (1) genetic variants in the YKL-40 gene are associated to plasma levels of YKL-40 in the general population; (2) genetic variants in the YKL-40 gene are a risk factor for future cancer; and (3) genetic variants in the YKL-40 gene are associated to certain types of cancer.

Plasma YKL-40 has also been determined in a prospective, population based study of 4987 subjects (aged 18-97 years) referred to endoscopy due to symptoms or other risk factors for colorectal cancer. 303 subjects were diagnosed with colorectal cancer [46]. Multivariate logistic regression analysis including plasma YKL-40, carcinoembryonic (CEA), age, sex, BMI, smoking, alcohol intake and comorbidity demonstrated that plasma YKL-40 independently predicted colorectal cancer [47].

Recently, it was reported that plasma YKL-40, carbohydrate antigen 19-9 (CA-19-9) and osteopontin in combination had superior sensitivity for detection of locally advanced, stage II/III pancreatic cancer compared to CA 19-9 alone (93\% vs. 80\%) [29]. Studies are therefore ongoing to evaluate if plasma YKL-40 in combination with a panel of other biomarkers can be of value for detection of pancreatic cancer at an early stage.

These studies suggest that plasma YKL-40 may be useful in the assessment of early detection of gastrointestinal cancer, but the results should be validated. It is also unknown if plasma YKL-40 could be used for risk assessment of other types of adenocarcinoma. 


\subsubsection{Prevalence of High Plasma YKL-40 Levels}

Plasma YKL-40 is elevated, defined as higher than the age-adjusted $95^{\text {th }}$ percentile of plasma YKL-40 in healthy subjects, in some patients with primary or advanced adenocarcinoma of the breast [33,48-51], colorectal [52-54], endometrial [55], lung [56], pancreas [28,29,57], prostate [58-60], ovary [36,61-65] and cervix [66]. Highest plasma YKL-40 levels are found in patients with advanced cancer. The percentage of patients with elevated plasma YKL-40 was highest in patients with metastatic pancreatic and ovarian adenocarcinoma, $\sim 80 \%$ of these patients had elevated plasma YKL-40, Figure 4. These types of cancer are characterized by a very dismal prognosis.

Figure 4. The percentage of patients with elevated plasma YKL-40 is calculated as the number of patients in the different studies with plasma YKL-40 higher than the age-adjusted 95th percentile of plasma YKL-40 in healthy subjects.

\section{$\%$ of patients with elevated plasma YKL-40 \\ compared to age-matched healthy subjects}

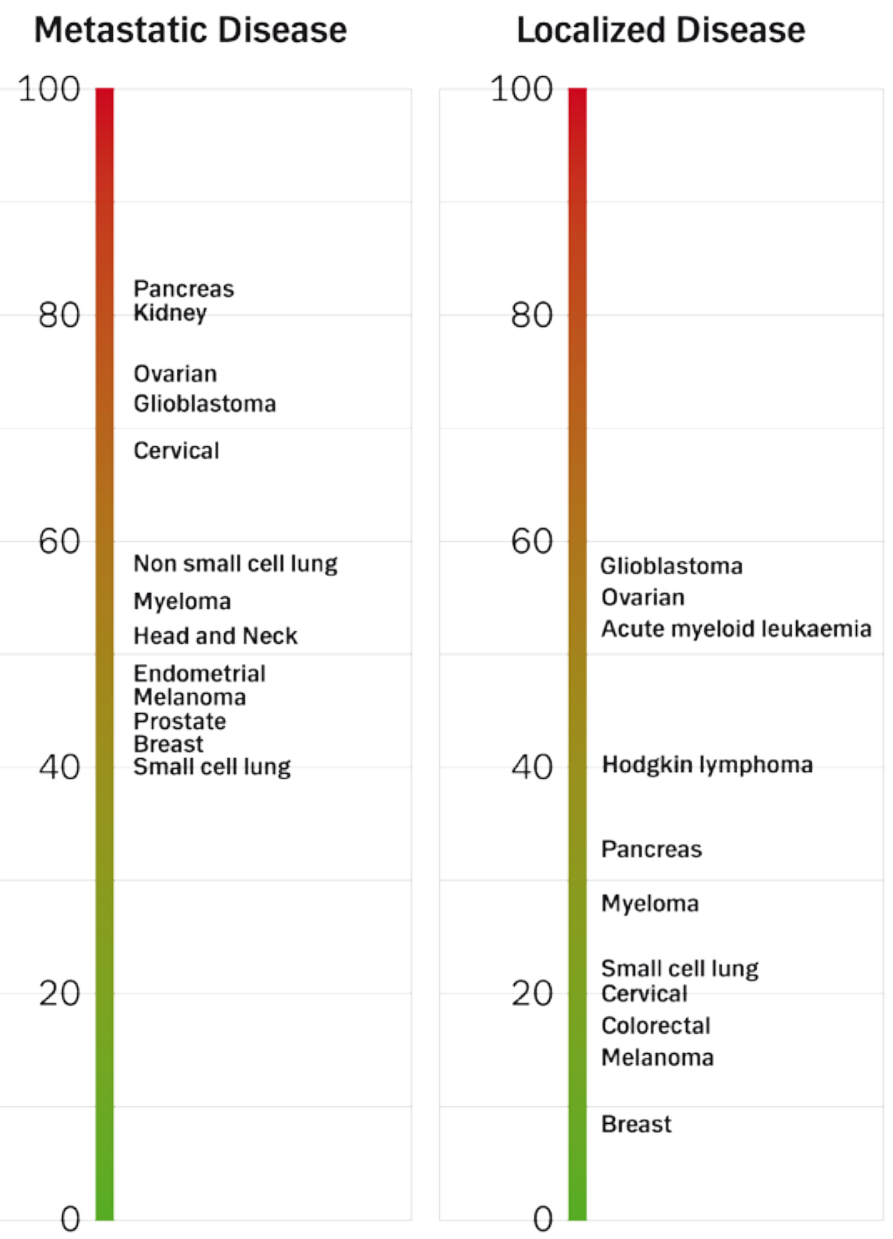

\subsubsection{Prognosis}

High pre-treatment plasma YKL-40 is an independent prognostic biomarker of short overall survival in patients with different types of adenocarcinoma, Table 1. This was found in patients with 
localized or advanced breast [32,48-51], colorectal [52-54], endometrial [55], non-small cell lung [56], ovary [36,61-64], cervix [66] and prostate [58-60] adenocarcinoma both at time of first cancer diagnosis and at time of relapse. Plasma YKL-40 was independent of other routinely used biomarkers (i.e., estrogen receptor status, KRAS mutation status, serum levels of human epidermal growth factor receptor 2 (HER2), CEA, carbohydrate antigen (CA) 125, prostate-specific antigen (PSA) and lactate dehydrogenase (LDH) and clinical parameters (i.e., age, performance status, tumor stage, histology) when tested in multivariate Cox analysis [32,36,48-56,58-64,66]. In many of these studies, but not all, pre-treatment plasma YKL-40 was also a prognostic biomarker of recurrence- or progression-free interval. Plasma YKL-40 may therefore provide additional information of prognosis in patients with different types of adenocarcinoma.

Table 1. Pretreatment plasma YKL-40 is an independent prognostic biomarker of overall survival in cancer patients. The results are from multivariate Cox regression analysis including clinical characteristics and other routine prognostic variables.

\begin{tabular}{llllll}
\hline Diagnosis & Number & Treatment & HR (95\% CI) & P-value & Ref. \\
\hline Primary breast cancer & 271 & Surgery + Chemotherapy & $1.8(1.0-3.1)$ & 0.04 & 49 \\
Metastatic breast cancer & 100 & Chemotherapy & $2.6(1.6-4.1)$ & 0.0002 & 48 \\
Colorectal cancer & 603 & Surgery & $1.4(1.1-1.8)$ & 0.007 & 52 \\
Metastatic colorectal cancer & 155 & Chemotherapy + Biologics & $1.2(1.1-1.4)$ & 0.0045 & 54 \\
Ovarian cancer, stage III & 47 & Surgery + Chemotherapy & $4.0(1.5-10.3)$ & 0.005 & 61 \\
Ovarian cancer, 1. relapse & 73 & Chemotherapy & $2.3(1.3-4.1)$ & 0.006 & 62 \\
Ovarian cancer, stage I-IV & 76 & Surgery + Chemotherapy & $2.1(1.4-3.2)$ & 0.0004 & 36 \\
Metastatic prostate cancer & 150 & Endocrine therapy & $1.3(1.0-1.7)$ & 0.02 & 58 \\
Renal cancer & 58 & IL-2 & $3.0(1.2-7.0)$ & 0.014 & 72 \\
Small cell lung cancer & 131 & Chemotherapy & $1.9(1.1-3.4)$ & 0.02 & 71 \\
Metastatic NSCLC & 189 & Chemotherapy & 1.50 & 0.0002 & 56 \\
Cervical, adenocarcinoma & 37 & Surgery or Chemoradiation & $11(1.3-97) \S$ & 0.03 & 66 \\
Head- and neck cancer & 138 & Radiotherapy & $2.2(1.4-3.4)$ & 0.0006 & 68 \\
Melanoma I-II & 234 & Surgery & $3.6(1.7-7.7)$ & 0.001 & 74 \\
Melanoma IIB-III* & 147 & Surgery & $1.8(1.2-2.7)$ & 0.008 & 75 \\
Melanoma IV & 110 & IL-2, IFN & $1.9(1.2-2.8)$ & 0.004 & 73 \\
Acute myeloid leukemia & 78 & Chemotherapy & $1.4(1.1-1.7)$ & 0.0002 & 99 \\
Anaplastic astrocytoma & 38 & Surgery & $2.2(1.0-4.9)$ & 0.05 & 94 \\
Glioblastoma & 75 & Surgery & $1.4(1.1-1.9)$ & 0.02 & 94 \\
\hline
\end{tabular}

HR, Hazard Ratio; CI, Confidence Interval; NSCLC, Non small cell lung cancer; IL-2, Interleukin 2; IFN, Interferon- $\alpha$. In most of these studies plasma YKL-40 was log transformed and treated as a continuous variable. aCut-off level: $209 \mu \mathrm{g} / \mathrm{L} .{ }^{8}$ Cut-off level $130 \mu \mathrm{g} / \mathrm{L}$ and the results of disease free survival is shown.*Blood sample collected after primary operation.

\subsubsection{Treatment Response}

Few studies have evaluated if pre-treatment plasma YKL-40 is a predictor of treatment response. Plasma YKL-40 decreased in patients after curative operation for colorectal cancer, whereas patients with elevated plasma YKL-40 six months after operation had shorter recurrence-free interval and overall survival [53]. In patients with first recurrence of breast cancer high plasma YKL-40 predicted 
less responsiveness to anthracycline therapy [48], and high plasma YKL-40 was a predictor of secondline chemo resistance in patients with ovarian cancer [64]. Pre-treatment plasma YKL-40 was an independent prognostic biomarker in patients with metastatic prostate cancer treated with endocrine therapy [58]. Recently, we have found that high plasma YKL-40 in patients with metastatic colorectal cancer before 3. line treatment with cetuximab and irinotecan was associated with short progression free survival and short overall survival, independent of KRAS status [54].

\subsubsection{Monitoring}

Early changes in biomarkers are investigated as potential predictors of response. They may be useful in early identification of patients unlikely to benefit, so as to spare them ineffective and potentially toxic treatment. Furthermore, monitoring plasma biomarkers in cancer patients without evidence of disease might allow for earlier detection of recurrence. There is limited information regarding changes in plasma YKL-40 during treatment of cancer patients. Increases in plasma YKL-40 during follow-up after curative resection of colorectal cancer was related to increased risk of recurrence and death [53]. During treatment of patients with metastatic colorectal cancer with 3. line cetuximab and irinotecan plasma YKL-40 as well as the ratio of updated YKL-40 levels compared to pre-treatment levels were associated with progression free survival and overall survival, and high YKL-40 values indicated poor prognosis [54]. In patients with metastatic prostate cancer treated with endocrine therapy, high plasma YKL-40 during treatment was related to short survival [59]. In a small study of patients with locally advanced pancreatic cancer increased plasma YKL-40, compared to pre-treatment levels, four to six weeks after the end of radiochemotherapy, was associated with short overall survival [57]. In patients with metastatic pancreatic cancer, an increase in plasma YKL-40 four weeks after start of chemoradiotherapy was also associated with short survival [57].

\subsection{Squamous Cell Carcinoma}

\subsubsection{Tissue}

YKL-40 protein expression is high compared to normal tissue in head and neck, cervix and anal squamous cell carcinoma [66-69], Figure 3 E,F. YKL-40 protein expression was not associated with prognosis in head and neck squamous cell carcinoma [68], and has not been evaluated in cervix squamous cell carcinoma. In anal squamous cell carcinoma expression of YKL-40 was highest in keratinizing carcinoma and high expression was related to short survival [69].

\subsubsection{Prognosis, Treatment Response, and Monitoring}

Plasma YKL-40 is elevated, defined as higher than the age-adjusted $95^{\text {th }}$ percentile of plasma YKL-40 in healthy subjects, in 53\% of patients with head and neck cancer [69] and increased with stage in patients with cervix squamous cell carcinoma [66,67], Figure 4. High pre-treatment plasma level of YKL-40 is an independent prognostic biomarker of short overall survival in patients with head and neck and cervix squamous cell carcinoma $[67,68]$, Table 1 . It is not known if pre-treatment plasma YKL-40 is a predictor of treatment response in these patients. A longitudinal study of patients with squamous cell carcinoma of the head and neck (TNM stage III and IV) showed that lack of decrease in 
plasma YKL-40 two months after radiotherapy compared to pretreatment value was accompanied by short survival. Furthermore, an increase in plasma YKL-40 during follow-up in these patients predicted short survival [68].

\subsection{Small Cell Lung Carcinoma}

\subsubsection{Tissue}

YKL-40 mRNA expression is not found in small cell lung cancer cells but was high in the tumor associated macrophages [70]. Human and mice small cell lung cancer cells do not produce YKL-40 in vitro [70].

\subsubsection{Prognosis, Treatment Response, and Monitoring}

Plasma YKL-40 is elevated, defined as higher than the age-adjusted $95^{\text {th }}$ percentile of plasma YKL-40 in healthy subjects, in a subgroup of patients with localized or advanced small cell lung carcinoma [71], Figure 4. High pre-treatment plasma YKL-40 levels before chemotherapy independently predicted short survival [71], Table 1.

\subsection{Renal Cell Carcinoma}

\subsubsection{Tissue}

YKL-40 protein expression is found in renal cell carcinoma (personal observation, NCBI).

\subsubsection{Prognosis, Treatment Response, and Monitoring}

Plasma YKL-40 is elevated, defined as higher than the age-adjusted $95^{\text {th }}$ percentile of plasma YKL-40 in healthy subjects, in approximately $80 \%$ of patients with metastatic renal cell carcinoma [72]. Multivariate analysis including YKL-40, LDH and performance status showed that high plasma YKL40 was an independent biomarker of short survival [72], Table 1.

\subsection{Melanoma}

\subsubsection{Tissue}

YKL-40 protein expression is found in melanoma cells and in tumor associated macrophages, Figure 3G. It has not been evaluated if YKL-40 expression score in melanoma is related to progression free survival or overall survival. Melanoma cells in vitro produce YKL-40 (personal observation).

\subsubsection{Prognosis, Treatment Response, and Monitoring}

Plasma YKL-40 is elevated, defined as higher than the age-adjusted $95^{\text {th }}$ percentile of plasma YKL-40 in healthy subjects, in $45 \%$ of patients with metastatic melanoma and in $13 \%$ of patients with stage I melanoma [73,74], Figure 4. Pre-treatment plasma YKL-40 is an independent prognostic biomarker in patients with stage I, II, and IV melanoma [73,74]. High plasma YKL-40 in patients after 
surgery for stage IIB-III melanoma is associated with poor survival in patients not receiving adjuvant interferon therapy [75], Table 1. In patients operated for stage I and II melanoma an association was found between high plasma YKL-40 during follow-up and short recurrence-free survival and overall survival [74]. An increase in plasma YKL-40 compared to the previous measurement was also associated to shorter overall survival in stage IIB-III melanoma patients during follow-up or treatment with adjuvant interferon [75].

\subsection{Glioblastoma}

\subsubsection{Tissue}

In vitro, the U87 glioblastoma cell line [76,77] and the glioma cell lines U1242MG, U343MG and U1231MG [78] secrete YKL-40. Microarray gene analyses showed that YKL-40 is overexpressed, compared to normal tissue, in glioblastomas [79-88] and astrocytomas [78]. YKL-40 mRNA and protein expressions increases with glioma grade and are higher in glioblastoma than in astrocytic and oligodendroglial tumors [87,89-93]. Furthermore, YKL-40 expression is inversely associated with epidermal growth factor receptor (EGFR) in glioblastoma, with loss of chromosome 10q [89] and tends to be higher in astrocytomas with 10q23 loss of heterozygosity (LOH) [84,93]. High YKL-40 expression was associated with poor radiation response and short time to disease progression and death [77,84,89-91]. Underscoring YKL-40's association with behaviour, it has been identified as part of a nine-gene paraffin tissue-based expression panel that most closely predicts survival in patients with glioblastoma [94]. Patients with EGFRvIII-negative/YKL-40-negative tumors had the best prognosis [91]. High YKL-40 protein expression was also associated with loss of chromosome 10q but not with amplification of EGFR. In pediatric high-grade gliomas YKL-40 overexpression is less frequent than in adult high-grade gliomas and does not correlated with survival [95].

\subsubsection{Prognosis, Treatment Response, and Monitoring}

Plasma YKL-40 is elevated, defined as higher than the age-adjusted $95^{\text {th }}$ percentile of plasma YKL-40 in healthy subjects, in 57-72\% of patients with glioblastoma [81,94], Figure 4. Baseline plasma YKL-40 was an independent prognostic biomarker of decreased survival in patients glioblastoma [94], Table 1. In patients operated for high-grade gliomas plasma YKL-40 during follow-up was lower in patients with no radiographic evidence of disease compared to patients with signs of disease, and high plasma YKL-40 during follow-up was associated with short survival [94]. However, any benefit of initiating treatment on the basis of this information is not known.

\subsection{Hematological Malignancies}

\subsubsection{Tissue}

YKL-40 protein expression has not been evaluated in tissue from patients with leukemia and lymphoma. In myeloma, YKL-40 originates from cells in the bone marrow microenvironment surrounding the myeloma cells [96]. A few myeloma cell lines [96] and some tumor cell lines originating from immature cells of the monocytic differentiation lineage produce YKL-40 in vitro $[4,97,98]$. 


\subsubsection{Prognosis, Treatment Response, and Monitoring}

Plasma YKL-40 is elevated in some patients with acute myeloid leukemia [99], multiple myeloma [96,100,101], and Hodgkin lymphoma [102], and high pre-treatment plasma YKL-40 is associated with short survival $[96,99,100]$. Patients with myeloma and high plasma YKL-40 had more severe bone destruction including increased bone resorptive activity and early progression of myeloma-related bone disease [100]. In patients with Hodgkin lymphoma and myeloma high correlations were found between plasma YKL-40 and interleukin (IL)-6 [101,102].

\subsection{Cancer Stem Cells}

\subsubsection{Tissue}

YKL-40 protein expression is found in tissue from embryonal carcinoma, Figure 1D. There are no publications evaluating YKL-40 production by cancer stem cells.

\section{Plasma YKL-40 in Patients with Non-Malignant Diseases Characterized by Inflammation, Tissue Remodeling and Fibrosis}

High plasma YKL-40 levels are also found in patients with non-malignant diseases characterized by inflammation, increased extracellular tissue remodeling and ongoing fibrosis. It is therefore very important to take into account any co-morbiditiy in patients with cancer, since a high plasma YKL-40 level may also originate from non-malignant cells.

\subsection{Inflammatory Diseases}

YKL-40 is an acute phase protein because its plasma concentration increases more than $25 \%$ following an inflammatory stimulus. Plasma YKL-40 is suggested to be a biomarker of acute and chronic inflammation [25,103], including systemic low-grade inflammation [104]. In contrast to serum CRP, that is produced in the liver by hepatocytes in response to high IL-6 levels $[105,106]$, YKL-40 is produced locally in tissues with inflammation by macrophages and neutrophils. No or low correlations are found between plasma YKL-40 and CRP, suggesting that these biomarkers reflect different aspects of the inflammatory process, and that plasma YKL-40 provides independent information of inflammation.

Plasma YKL-40 correlated with plasma IL-6 levels in 80-year old women and men, and with serum tumor necrosis factor (TNF) $\alpha$ and CRP in 80-year old women. High plasma YKL-40 was also associated with a low CD4:CD8 cell ratio, and with all-cause mortality, independent of sex, smoking, BMI, chronic disease and anti-inflammatory medicine [104]. In 482 subjects without cardiovascular disease or type 2 diabetes plasma YKL-40 independently predicted cardiovascular mortality and all cause mortality [107].

\subsubsection{Infectious Diseases}

YKL-40 is located in the specific granules of neutrophils [108] and macrophages produce YKL-40 [3,4,19]. Patients with Streptococcus pneumoniae pneumonia, bacteremia and sepsis have 10-fold higher plasma YKL-40 compared to healthy subjects [109-111]. Human endotoxaemia, 
characterized by increased plasma TNF $\alpha$ and IL-6 levels, increases plasma YKL-40 [112]. Plasma and cerebrospinal fluid concentration of YKL-40 is associated to severity and prognosis of patients with bacterial infection, and plasma YKL-40 may add independent information of prognosis [109-111,113]. Plasma YKL-40 decreases faster to normal levels than CRP in patients who recover from an disease [109].

\subsubsection{Cardiovascular Diseases}

In vivo, YKL-40 is expressed by macrophages in atherosclerotic plaques [114]. In vitro YKL-40 is produced by macrophages during late state of differentiation $[3,4,19]$, by differentiated vascular smooth muscle cells [115-118] and by endothelial cells [119]. Recent studies suggest that plasma YKL-40 may be a potential biomarker in patients with cardiovascular disease [120-128]. Plasma YKL-40 increases in patients after an acute myocardial infarction [120,121] and is associated with the number of diseased vessels assessed by coronary angiography [122,123]. Plasma YKL-40 correlated with creatine kinase fraction B in non-thrombolyzed patients with acute myocardial infarction [120]. Elevated plasma YKL-40 is found in some patients with atrial fibrillation [124,125]. A study of 4298 patients with stable coronary artery disease showed that high plasma YKL-40 independently predicted cardiovascular mortality and all cause mortality [126]. It is not known if plasma YKL-40 reflects the total burden of coronary atherosclerosis or identifies a high-risk atherosclerosis phenotype with ongoing inflammation and severe atherosclerotic plaques. In a smaller study of patients with chronic heart failure plasma YKL-40 was elevated compared to healthy age-matched subjects, but was not associated with New York Heart Association (NYHA) classification, other clinical characteristics or prognosis [127].

\subsubsection{Diabetes}

Patients with type 2 diabetes have higher plasma YKL-40 levels compared to subjects with normal glucose tolerance $[9,129,130]$, and plasma YKL-40 is related to insulin resistance [129], fasting plasma glucose, and plasma IL-6 [130], but not to serum CRP [129] or obesity [130]. Patients with type 1 diabetes have elevated plasma YKL-40 compared to healthy subjects, and increasing plasma YKL-40 levels are associated with increasing levels of albuminuria [131]. It is suggested that plasma YKL-40 is an emerging biomarker in patients with cardiovascular disease and diabetes [132].

\subsubsection{Rheumatic Diseases}

YKL-40 is produced by arthritic chondrocytes [7,133,134], synoviocytes and fibroblast-like synovial cells $[7,135,136]$, and by macrophages in inflamed synovial tissue [133,137]. In patients with rheumatoid arthritis YKL-40 protein is expressed by CD16+ monocytes with a dim expression of CD14 [137]. This phenotype can differentiate from classic CD14++ monocytes by maturation in vitro and is considered as pro-inflammatory with properties of tissue macrophages and are a source of TNF $\alpha$ [138]. Patients with very active rheumatoid arthritis have elevated plasma YKL-40 [9,31,133,139-147] compared to healthy subjects and patients with inactive rheumatoid arthritis. Plasma YKL-40 is related to clinical parameters of disease activity and serum CRP, and in a few studies also with progression of joint destruction [139,140]. However, plasma YKL-40 did not provide better clinical information of disease activity and prognosis in patients with rheumatoid arthritis compared to serum CRP. 
Few patients with osteoarthritis have elevated plasma YKL-40 [133,148], and only if they have severe synovitis of large joints like a knee joint [133].

YKL-40 is expressed by macrophages and giant cells in arteritic vessels [119]. Patients with giant cell arteritis have elevated plasma YKL-40 at time of diagnosis, but during treatment with glucocorticoids plasma YKL-40 was not related to disease activity and serum CRP [119].

\subsubsection{Lung Diseases}

YKL-40 is expressed by macrophages in bronchial-biopsy specimens and cytospin of broncho-alveolar lavage from patients with asthma [149] and chronic obstructive pulmonary disease (COPD) [150], and in sarcoid lesions of patients with pulmonary sarcoidosis [151]. YKL-40 is also produced by mast cells [24,43]. YKL-40 concentrations in plasma and bronchoalveolar lavage are higher in smokers with COPD than smokers without COPD [150] and associated with airflow obstruction and impaired diffusion lung capacity. Plasma YKL-40 levels are elevated in some patients with asthma compared to healthy subjects, and is associated with the severity of asthma measured by clinical variables, including FEV1, and with thickness of the subepithelial basement membrane in biopsy specimens of the lung [149]. YKL-40 levels in plasma and bronchoalveolar-lavage-fluid increase 24 hours after allergen challenge in patients with allergic asthma, and correlate with eosinophil counts 24 hours after allergen challenge [149,152]. Plasma YKL-40 is higher in patients with pulmonary sarcoidosis compared to healthy subjects and correlated with serum angiotensin-converting enzyme [151]. Patients with systemic sclerosis and elevated plasma YKL-40 have poor prognosis and often die due to extensive interstitial or vascular fibrosing processes $[153,154]$. It has therefore been suggested that plasma YKL-40 is a potential new biomarker in patients with inflammatory lung diseases [103,155].

\subsubsection{Inflammatory Bowel Diseases}

Elevated plasma YKL-40 levels are found in patients with active inflammatory bowel disease [142,156-159]. In patients with ulcerative colitis plasma YKL-40 correlated with serum CRP and a disease activity score [156,158]. In patients with Crohn's disease both low relations between plasma YKL-40 and disease activity score [158], and high relations between plasma YKL-40 and activity score [156] are reported. Patients with inflammatory bowel disease and joint involvement have higher plasma YKL-40 than patients without joint involvement [157]. Patients with Crohn's disease and stenotic disease have higher plasma YKL-40 than patients with non-stenotic disease and plasma YKL-40 was independent of other clinical parameters [156,159]. Thus, plasma YKL-40 may reflect ongoing fibrogenesis and may be a risk factor in patients with Crohn's disease.

\subsection{Liver Fibrosis}

High YKL-40 protein expression is found in fibrotic liver tissue from patients with alcoholic liver disease and chronic hepatitis C virus infection [160,161]. Hepatocytes do not express YKL-40 protein and no expression is found in normal liver tissue except in mesenchymal structures of the portal tract. It is most likely that hepatic stellate cells, leucocytes and macrophages produce YKL-40 in the fibrotic liver [160,161]. In biopsies with chronic active hepatitis C virus YKL-40 protein expression was found in areas with piecemeal necrosis, but not in lymphocytes. 
In 8899 subjects from the general population increasing plasma levels of YKL-40 were found with increasing alcohol intake [27]. Plasma YKL-40 is elevated in most patients with moderate to severe liver fibrosis and cirrhosis, independently of disease etiology, and may provide new information of ongoing fibrogenesis in the liver [160-178]. In patients with alcoholic liver disease elevated plasma YKL-40 is related to liver fibrosis and inflammation in the liver [160,161,164], and patients with very high plasma YKL-40 have shorter survival than patients with normal plasma YKL-40 [163]. Plasma YKL-40 predict cirrhosis (Ishak 5/6) in patients with chronic hepatitis C, but was not included in the final three-variable model consisting of serum hyaluronan, tissue inhibitor of metalloprotinases (TIMP)-1 and platelet count [171,172]. In children, plasma YKL-40 could not differentiate patients with advanced liver fibrosis from those with mild fibrosis [173].

\section{What Is the Function of YKL-40?}

The biological functions of YKL-40 in cancer are unknown. YKL-40 may play different roles depending upon the cell types and environment. YKL-40 probably has a role in proliferation and differentiation of malignant cells and protects the cells from apoptosis. YKL-40 also stimulates angiogenesis and has an effect on extracellular tissue remodeling, and YKL-40 regulates fibroblast activity and increases the degree of fibrosis surrounding cancer cells, although in vivo proofs are yet to be obtained [25,34,35]. Membrane receptors of YKL-40 are not described. YKL-40 induced activation of intracellular signal-transduction pathways suggests that it interacts with signaling components on the cell membrane [179-181]. A thorough understanding of the pathobiology of a putative novel biomarker is not essential regarding its diagnostic or prognostic performance as a biomarker. However, pathophysiological information is very useful in providing support for the validity of the clinical observations, as well as direct research that pertains to possible diagnostic and therapeutic applications.

\subsection{Single Nucleotide Polymorphism (SNP)}

Studies are ongoing to describe genetic variants of YKL-40 in the general population. The level of YKL-40 expression may in some cases be genetically regulated. The most tested SNP-131 C/G in the promoter region of the YKL-40 gene did not differ between patients with glioblastoma and controls, and no correlation was found between this genotype and YKL-40 expression in glioblastoma samples [182]. There was no difference in survival between the CC, CG, and GG glioblastoma patients despite the few GG patients tended to have a longer survival [182]. In other diseases SNP-131 C/G is associated with: (1) elevated plasma YKL-40 levels in patients with asthma, bronchial hyper responsiveness and pulmonary function in the Hutterites [183]; and (2) plasma YKL-40 levels and the severity of hepatitis $C$ virus induced liver fibrosis [162]. An association is found between schizophrenia and haplotypes within the promoter region of the YKL-40 gene including SNP-131 C/G [184-186]. A meta-analysis suggests that the genetic variants in the YKL-40 gene have ethnic heterogeneity and confer a susceptibility to schizophrenia in Asian populations [186]. In patients with rheumatoid arthritis no association was found to SNP-131 C/G [187]. SNP-329 G/A in the YKL-40 gene are related to plasma YKL-40 levels in healthy subjects but not in patients with sarcoidosis [188]. In Danish patients with type 2 diabetes [189] and asthma and atopy [190] none of the reported SNPs or haplotype blocks of the YKL-40 gene were associated with these diseases. 


\subsection{Growth Factor}

Studies of embryonic and fetal cells [5], macrophages [3,4,19,191-193] and fetal chondrocytes [5,194-196] suggest that YKL-40 is a proliferation and differentiation marker. YKL-40 is strongly expressed in the three germ layers of human embryos and exists in two different isoforms in early human fetal tissue derivatives of ecto-, meso- and endoderm. At the cellular level YKL-40 protein expression was high in embryonic and fetal tissues characterized by rapid proliferation and marked differentiation, and in tissues undergoing morphogenetic changes [5]. We have also observed that YKL-40 is produced by undifferentiated human embryonic stem cells and their progenitors in differentiating human embryonic stem cells colonies [23]. Embryonal carcinoma also expresses YKL-40 protein and studies are ongoing to test if YKL-40 is produced by different types of cancer stem cells.

\subsection{Protection Factor}

YKL-40 expression increases in human glioblastoma cells following stress stimuli such as hypoxia, serum depletion, ionizing radiation and chemotherapy [76]. The response is late, 24 hours to 72 hours after stimuli, indicating that YKL-40 is a secondary response downstream of other mechanisms. Astrocytes transfected with YKL-40 have increased resistance to serum depletion and radiation as well as increased invasion potential [84]. Tumor growth of the human U87 glioblastoma cells as xenografts on nude mice is delayed by treatment with monoclonal antibodies against human YKL-40 [197], suggesting that YKL-40 may be a potential cancer target. In vivo, in glioblastoma cells, a positive association between YKL-40 and activated AKT1 pathways and MAPK intermediates was found [91]. It was hypothesized that YKL-40 as a secreted protein may serve as an extracellular signal, inducing increased downstream activity of Ras [198], or may be a surrogate measurement of Ras/PI3-K activation [91].

YKL-40 initiates PI-3K signalling pathways and phosphorylation of AKT [179-181] and may be an anti-apoptotic protein [199]. YKL-40 is also called "breast regression protein (Brp-39)" [15], since it is induced in mice mammary epithelial cells a few days after weaning. Mammary involution involves programmed cell death. It is suggested that YKL-40 utilizes a chitin oligosaccharide binding ability while participating in the various signal transduction pathways that leads to apoptosis of the regressing cells and that YKL-40 is a protective signalling factor determining which cells are to survive the high tissue remode that occurs during involution [13].

\subsection{Angiogenesis}

A recent study has identified YKL-40 as a promoter of angiogenesis in cancer, including activating the MAPK/ERK pathway in endothelial cell [200]. Transfection of the human glioblastoma cell line U87 with short-interfering RNA against vascular endothelial growth factor (VEGF-A) and implantation on a chick chorio-allantoic membrane resulted in an up-regulation of YKL-40 [77]. This suggests a role of YKL-40 in regulating response of cancer cells to hypoxia. YKL-40 is also synthesized by vascular smooth muscle cells [8,115-118], stimulates migration of endothelial cells [117], and promotes vascular smooth muscle cell attachment, spreading and migration [118] suggesting a function in angiogenesis and thereby playing a role in the growth of the tumor [201]. 


\subsection{Inflammation}

YKL-40 plays a pathogenetic role in colitis by enhancing the adhesion and invasion of bacteria on/into colonic epithelial cells, and leads to exacerbations of intestinal inflammation [202-204]. YKL-40 is an autoantigen in rheumatoid arthritis and may have a fundamental role in the pathophysiology of rheumatoid arthritis [137,205-211]. Studies of patients with asthma suggest that YKL-40 has a role in the innate immune response [149,212]. A study of Brp-39 (the mouse homologue of YKL-40) in Brp-39 ${ }^{-1}$ mice, YKL-40 transgenic mice, and mice that lack Brp-39 and produce YKL-40 only in their pulmonary epithelium found that Brp-39/YKL-40 has several important functions: (1) it is an inhibitor of macrophage, T-cell, and eosinophil death receptor-mediated apoptosis/cell death and is associated with augmented protein kinase B (PKB)/AKT phosphorylation and Faim 3 induction; (2) it plays a role in the pathogenesis of the IL-13 effector responses that generate inflammation and air-way remodelling; (3) it stimulates accumulation and activation of pulmonary dendritic cells and macrophages; and (4) it is involved in antigen-induced sensitization and IgE induction [199].

\subsection{Tissue Remodeling and Development of Fibrosis}

The stroma around the periphery of solid tumors has many similarities with granulation tissue such as that found in wound-healing or inflammation, and regulates essential aspects of tumor proliferation, cell death, progression, matrix remodeling and angiogenesis, and subsequently promotes tumor growth and progression of metastatic disease [213-222]. YKL-40 is a proliferation factor of fibroblasts [14,179] and acts synergistically with IGF-1 [179]. YKL-40 secreted by cancer cells and inflammatory cells surrounding and infiltrating the tumor may play a role in proliferation, activation and differentiation of the fibroblasts/myofibroblasts surrounding the tumor. YKL-40 could thereby influence development of the prominent desmoplastic stroma seen in both primary cancer and metastatic sites. This phenomenon, termed stromal reaction, includes activation of fibroblasts and myofibroblasts transformation, inflammation, secretion of cytokines, matrix proteins and metalloproteinases, and angiogenesis. All play a role in cancer development and metastatic potential, affecting the proliferation, differentiation, invasion or regression of cancer cells, particularly in cancers of epithelial origin [221,223-226].

YKL-40 is regulated in chondrocytes by TNF $\alpha$ [180,181] and requires sustained activation of NF- $\kappa B$ [181], which controls cell survival by regulating cell proliferation, growth arrest and death [214]. YKL-40 initiates MAP kinase and PI-3K signalling cascades in fibroblasts leading to phosphorylation of the extracellular signal-regulated kinase (ERK)-1/2 MAP kinase and $\mathrm{PKB} / \mathrm{AKT}$-mediated signalling cascades, which are associated with the control of mitogenesis [179-181]. Stimulation of articular chondrocytes or skin fibroblasts with IL-1 or TNF $\alpha$ in the presence of YKL-40 results in reduction of both p38 and SAPK/JNK phosphorylation, and YKL-40 suppresses the cytokineinduced secretion of several metalloproteinase and the chemokine IL-8 [181]. This suggests that YKL-40 may play a protective role in inflammatory environments, limiting degradation of the extracellular matrix and thereby controlling tissue remodelling.

YKL-40 binds collagen type I, II and III and modulates the rate of type I collagen fibril formation [227]. YKL-40 also binds chitin, but has no chitinase activity [7,19,21] due to amino acid 
substitution in the active site of chitinases [7,19]. YKL-40 contributes to chondrocyte differentiation by inducing the transcription factor SOX9 and type II collagen expressions, and the induction of SOX9 depends on ERK1/2 and PI3K activities, but not on p38 and JNK MAPK [228]. Vertebrates in an embryonic stage use short chito-oligosaccharides as primers for the synthesis of hyaluronan [229-231]. YKL-40 has heparin and hyaluronan binding motifs [20] and may bind to cell surface receptors such as heparin sulphate proteoglycans and may recognize hyaluronan or its precursor as a substrate in the extracellular matrix and interfere with the synthesis and local concentrations of hyaluronan [20]. YKL-40 may influence the effects of high hyaluronan in tissues, e.g., the extent of cell adhesion and migration during the tissue remodelling processes that take place during metastasis, inflammation, fibrosis, and atherogenesis [232,233]. Furthermore, YKL-40 secreted from macrophages in adipose tissue inhibits degradation of type I collagen and increases the rate of fibril formation of type I collagen [234].

\section{Plasma YKL-40—A New Cancer Biomarker?}

The first paper regarding plasma YKL-40 levels in cancer patients was published in 1995 [32]. Unfortunately, it is still unknown whether determination of plasma levels of YKL-40 can be useful in clinical practice. The pivotal criterion with regard to the potential clinical value of a candidate cancer biomarker is the consistency and strenght of the association between the biomarker and the outcome or disease of interest, and the extent to which it is an improvement on either adding to or replacing established tools. The clinical utility of the biomarker should also be demonstrated by showing that result-based decisions improve patient outcome [235-238].

It needs to be determined if routine measurement of plasma YKL-40 in patients with cancer can provide useful clinical information for risk assessment, for treatment selection or for monitoring patients after intervention with different therapeutics. At present plasma YKL-40 can not be regarded as a new cancer biomarker, and FDA has not yet approved the use of plasma YKL-40 as a biomarker in patients with cancer or any other disease. Assessment of the clinical potential of a novel biomarker can be structured around three fundamental questions [239]:

- Can the clinician measure the biomarker and is the method specific, sensitive, fast and cheap?

- Does the biomarker level add new information of the disease?

- Does the biomarker level help the clinician to treat patients?

Plasma levels of YKL-40 can be measured accurately and fast with relatively low cost, but it is not known if plasma YKL-40 in an individual cancer patient is so reliable that it can be used to make clinical decisions that will improve outcome of the patient.

In order to propose guidelines on how promising tumor markers progress from the laboratory into the clinic, Hayes introduced the “Tumor Marker Utility Grading System” [236,237]. According to this system a number of validation requirements have to be fulfilled before plasma YKL-40 can be considered to be a cancer biomarker. Most of the plasma YKL-40 biomarker studies are retrospective and the blood samples were not collected with the intent of testing the value of plasma YKL-40 as a diagnostic, prognostic, predictive and monitoring biomarker. There are therefore many limitations to the conclusions made from the present studies of plasma YKL-40 as a biomarker. According to the “Tumor Marker Utility Grading System” guidelines [236,237], the next step would be to launch an appropriate prospective study where the benefit of using plasma YKL-40 levels in the clinical 
decision-making process is assessed. Endpoints should include overall survival, disease-free survival, quality of life and cost-effectiveness. The study could be designed either as a single, highly-powered, prospective, controlled study with the primary objective of testing plasma YKL-40 level as a "prognosticator" or a similar prospective study where the primary goal could be the testing of a therapeutic hypothesis and secondly testing plasma YKL-40 as a biomarker. Such studies will hopefully be designed. Recently, it has been reported that YKL-40 in combination with a panel of biomarkers can give important information in preclinical drug development [240].

The term "cancer biomarker" embraces a spectrum of molecules of widely divergent characteristics, but sharing an association with malignancy that facilitates their application in the clinical detection (screening, diagnosis) and management (prognosis, monitoring) of cancer patients [238]. Table 2 summarizes what is presently known about plasma YKL-40 as a potential new cancer biomarker. YKL-40 is neither organ nor tumor specific. Plasma YKL-40 levels may have a role in screening for gastrointestinal cancer or identifying patients at risk [27,47]. Elevated plasma YKL-40 levels, compared to age-matched healthy subjects, are found in patients with 16 different types of cancer. Eighteen studies of 13 different types of cancer have shown that high pretreatment plasma YKL-40 is related to poor prognosis. Highest plasma YKL-40 levels are found in patients with metastatic cancer and plasma YKL-40 provides independent information of recurrence- and progression free survival and of overall survival. The potential values of plasma YKL-40 as a biomarker in monitoring and screening of cancer need more studies, and its value in combinations with other biomarkers has to be determined. It is likely that plasma YKL-40 should be combined in panels of biomarkers for optimal clinical use, since most biomarkers will probably individually lack optimal sensitivity and specificity. A study of patients with pancreatic cancer suggests that this may be useful [29].

Table 2. Is plasma YKL-40 a new cancer biomarker?

\section{Tumor specific?}

No-YKL-40 is also produced by non-malignant cells, e.g., inflammatory cells.

\section{High specificity for cancer?}

No-Plasma YKL-40 is also elevated in patients with diseases characterized by acute or chronic inflammation, tissue remodeling and fibrosis; i.e., co-morbidity shall always be considered in cancer patients with high plasma YKL-40.

\section{High sensitivity for cancer?}

No-Plasma YKL-40 is only elevated in a subgroup of cancer patients.

\section{Useful for screening?}

???-Plasma YKL-40 is elevated many years before a gastrointestinal cancer is diagnosed; more studies are needed.

\section{Reflect poor prognosis?}

Yes-High plasma YKL-40 reflects poor prognosis and is independent of other routinely used biomarkers.

\section{Predictor of treatment response?}

???-High plasma YKL-40 reflects poor treatment response in some patients; more studies are needed.

\section{Useful for monitoring?}

???-High plasma YKL-40 may reflects disease progression; more studies are needed. 
However, YKL-40 is not cancer specific, and high plasma YKL-40 levels are also found in patients with diseases characterized by inflammation, tissue remodelling and fibrosis. Co-morbidity should therefore always be considered in cancer patients.

\section{Future}

Much more basic research related to the function and regulation of YKL-40 is needed and many fundamental questions regarding YKL-40 remain to be answered. The biological functions of YKL-40 are unclear and its role in cancer development and the mechanisms by which it reflects cancer aggressiveness and cancer progression are poorly understood. The mechanisms by which stimuli lead to increased expression and synthesis of YKL-40 are unknown. It is likely that YKL-40 has a receptor, but it has not yet been identified. YKL-40 is produced by embryonic stem cells and embryonal carcinoma, and it probably has important roles in both embryonic and fetal growth and in pathological growth like cancer. It deserves to be tested if cancer stem cells produce YKL-40, and if the protein is related to metastatic potential in combination with a function in inflammation, angiogenesis, apoptosis and tissue remodeling processes and in pathological conditions leading to fibrosis.

Future focused translational research projects combining basic and clinical research are needed in a joint effort to answer the questions:

- Is plasma YKL-40 a useful clinical biomarker in patients with cancer?

- Is YKL-40 a target for development of new cancer therapeutics?

and with close collaborations between multidisciplinary teams including surgeons, oncologists, pathologists, biochemists, tumor biologists, molecular biologists, biotech companies and the pharmaceutical industry. Without such collaboration it is unlikely that these two questions will ever be answered.

\section{Acknowledgements}

The authors thank Kjeld Møllgård, University of Copenhagen for preparing Figure 1.

\section{References}

1. Siena, S.; Sartore-Bianchi, A.S.; Di Nicolantonio, F.; Balfour, J.; Bardelli, A. Biomarkers predicting clinical outcome of epidermal growth factor receptor-targeted therapy in metastatic colorectal cancer. J. Natl. Cancer Inst. 2009, 101, 1308-1324.

2. Atkinson, A.J., Jr. Biomarkers and surrogate endpoints: Preferred definitions and conceptual framework. Clin. Pharmacol. Ther. 2001, 69, 89-95.

3. Rehli, M.; Krause, S.W.; Andreesen, R. Molecular characterization of the gene for human cartilage gp-39 (CHI3L1), a member of the chitinase protein family and marker for late stages of macrophage differentiation. Genomics 1997, 43, 221-225.

4. Rehli, M.; Niller, H.H.; Ammon C.; Langmann, S.; Schwarzfischer, L.; Andreesen, R.; Krause S.W. Transcriptional regulation of CHI3L1, a marker gene for late stages of macrophage differentiation. J. Biol. Chem. 2003, 278, 44058-44067. 
5. Johansen, J.S.; Høyer, P.E.; Larsen, L.A.; Price, P.A; Møllgård, K. YKL-40 protein expression in the early developing human musculoskeletal system. J. Histochem. Cytochem. 2007, 55, 1213-1228.

6. Johansen, J.S.; Williamson, M.K.; Rice, J.S.; Price, P.A. Identification of proteins secreted by human osteoblastic cells in culture. J. Bone Miner. Res. 1992, 7, 501-512.

7. Hakala, B.E.; White, C.; Recklies, A.D. Human cartilage gp-39, a major secretory product of articular chondrocytes and synovial cells, is a mammalian member of a chitinase protein family. J. Biol. Chem. 1993, 268, 25803-25810.

8. Shackelton, L.M.; Mann, D.M.; Millis A.J.T. Identification of a 38-kDa heparin-binding glycoprotein (gp38k) in differentiating vascular smooth muscle cells as a member of a group of proteins associated with tissue remodeling. J. Biol. Chem. 1995, 270, 13076-13083.

9. Harvey, S.; Weisman, M.; O'Dell, J.; Scott, T.; Krusemeier, M.; Visor, J.; Swindlehurst, C. Chondrex: new marker of joint disease. Clin. Chem. 1998, 44, 509-516.

10. Bussink, A.P.; Speijer, D.; Aerts, J.M.F.G.; Boot, R.G. Evolution of mammalian chitinase(-like) members of family 18 glycosyl hydrolases. Genetics 2007, 177, 959-970.

11. Funkhouser, J.D.; Aronson, N.N. Chitinase family GH18: evolutionary insights from the genomic history of a diverse protein family. BMC Evol. Biol. 2007, 7, 96.

12. Zaheer-ul-Haq, Dala, P.; Aronson, N.N.; Madura, J.D. Family 18 chitolectins: comparison of MGP40 and HUMGP39. Biochem. Biophys. Res. Commun. 2007, 359, 221-226.

13. Mohanty, A.K.; Singh, G.; Paramasivam, M.; Saravanan, K.; Jabeen, T.; Sharma, S.; Yadav, S.; Kaur, P.; Kumar, P.; Srinivasan, A.; Singh, T.P. Crystal structure of a novel regulatory $40 \mathrm{kDa}$ mammary gland protein (MGP-40) secreted during involution. J. Biol. Chem. 2003, 278, 14451-14460.

14. De Ceuninck, F.; Gaufillier, S.; Bonnaud, A.; Sabatini, M.; Lesur, C.; Pastoureau, P. YKL-40 (cartilage gp-39) induces proliferative events in cultured chondrocytes and synoviocytes and increases glycosaminoglycan synthesis in chondrocytes. Biochem. Biophys. Res. Commun. 2001, 285, 926-931.

15. Morrison, B.W.; Leder, P. Neu and ras initiate murine mammary tumors that share genetic markers generally absent in c-myc and int-2-initiated tumors. Oncogene 1994, 9, 3417-3426.

16. Kirkpatrick, R.B.; Matico, R.E.; McNulty, D.E.; Strickler, J.E.; Rosenberg, M. An abundantly secreted glycoprotein from Drosophila melanogaster is related to mammalian secretory proteins produced in rheumatoid tissues and by activated macrophages. Gene 1995, 153, 147-154.

17. Kawamura, K.; Shibata, T.; Saget, O.; Peel, D.; Bryant, P.J. A new family of growth factors produced by the fat body and active on Drosophila imaginal disc cells. Development 1999, 126, 211-219.

18. Badariotti, F.; Kypriotou, M.; Lelong, C.; Dubos, M.P.; Renard, E.; Galera, P.; Favrel, P. The phylogenetically conserved molluscan chitinase-like protein 1 (Cg-Clp1), homologue of human HC-gp39, stimulates proliferation and regulates synthesis of extracellular matrix components of mammalian chondrocytes. J. Biol. Chem. 2006, 281, 29583-29596.

19. Renkema, G.H.; Boot, G.R.; Au, F.L.; Donker-Koopman, W.E.; Strijland, A.; Muijsers, A.O.; Hrebicek, M.; Aerts, J.M.F.G. Chitotriosidase, a chitinase, and the 39-kDa human cartilage 
glycoprotein, a chitin-binding lectin, are homologues of family 18 glycosyl hydrolases secreted by human macrophages. Eur. J. Biochem. 1998, 251, 504-509.

20. Fusetti, F.; Pijning, T.; Kalk, K.H.; Bos, E.; Dijkstra, B.W. Crystal structure and carbohydrate binding properties of the human cartilage glycoprotein-39. J. Biol. Chem. 2003, 278, 37753-37760.

21. Houston, D.R.; Recklies, A.D.; Krupa, J.C.; van Aalten, D.M.F. Structure and ligand-induced conformational change of the 39-kDa glycoprotein from human articular chondrocytes. J. Biol. Chem. 2003, 278, 30206-30212.

22. Henrissat, B.; Davies, G. Structural and sequence-based classification of glycoside hydrolases. Curr. Opin. Struct. Biol. 1997, 7, 637-644.

23. Johansen, J.S.; Møllgård, K. YKL-40: Common and distinct in cancer and autoimmunity, frequent in early development and abundant in human embryonic stem cells. In International Symposium Honoring Prof. David Naor, Ein Kerem, Jerusalem, Israel, 2-3 September 2007; Abstract 18.

24. Ringsholt, M.; Høgdall, E.V.S.; Johansen, J.S.; Price, P.A.; Christensen, L.H. YKL-40 protein expression in normal human tissues - an immunohistochemical study. J. Mol. Histol. 2007, 38, 33-43.

25. Johansen, J.S. Studies on serum YKL-40 as a biomarker in diseases with inflammation, tissue remodeling, fibrosis and cancer. Dan. Med. Bull. 2006, 53, 172-209.

26. Johansen, J.S.; Lottenburger, T.; Nielsen, H.J.; Jensen, J.E.B.; Svendsen, M.N.; Kollerup, G.; Christensen, I.B. Diurnal, weekly, and long-time variation in serum concentrations of YKL-40 in healthy subjects. Cancer Epidemiol. Biomarkers Prev. 2008, 17, 2603-2608.

27. Johansen, J.S.; Bojesen, S.E.; Mylin, A.K.; Frikke-Schmidt, R.; Price, P.A.; Nordestgaard, B.G. Elevated plasma YKL-40 predicts increased risk of gastrointestinal cancer and decreased survival after any cancer diagnosis in the general population. J. Clin. Oncol. 2009, 27, 572-578.

28. Fredriksson, S.; Horecka, J.; Brustugun, O.T.; Schlingemann, J.; Koong, A.C.; Tibshirani, R.; Davis, R.W. Multiplexed proximity ligation assays to profile putative plasma biomarkers relevant to pancreatic and ovarian cancer. Clin. Chem. 2008, 54, 582-589.

29. Chang, S.T.; Zahn, J.M.; Horecka, J.; Kunz, P.L.; Ford, J.M.; Fisher, G.A.; Le, Q.T.; Chang, D.T.; Ji, H.; Koong, A.C. Identification of a biomarker panel using a multiplex proximity ligation assay improves accuracy of pancreatic cancer diagnosis. J. Transl. Med. 2009, 7, 105.

30. Høgdall, E.V.S.; Johansen, J.S.; Kjaer, S.K.; Price, P.A.; Blaakjaer, J.; Høgdall, C.K. Stability of YKL-40 concentration in blood samples. Scand. J. Clin. Lab. Invest. 2000, 60, 247-252.

31. Johansen, J.S.; Jensen, H.S.; Price, P.A. A new biochemical marker for joint injury. Analysis of YKL-40 in serum and synovial fluid. Br. J. Rheumatol. 1993, 32, 949-955.

32. Johansen, J.S.; Cintin, C.; Jørgensen, M.; Kamby, C.; Price, P.A. Serum YKL-40: a new potential marker of prognosis and location of metastases of patients with recurrent breast cancer. Eur. $J$. Cancer 1995, 31A, 1437-1442.

33. Roslind, A.; Johansen, J.S. YKL-40: a novel marker shared by chronic inflammation and oncogenic transformation. Methods Mol. Biol. 2009, 511,159-184. 
34. Johansen, J.S.; Jensen, B.V.; Roslind, A.; Nielsen, D.; Price, P.A. Review. Serum YKL-40, a new prognostic biomarker in cancer patients? Cancer Epidemiol. Biomarkers Prev. 2006, 15, 194-202.

35. Johansen, J.S.; Jensen, B.V.; Roslind, A.; Price, P.A. Review. Is YKL-40 a new therapeutic target in cancer? Expert Opin. Ther. Targets 2007, 11, 219-234.

36. Høgdall, E.V.S.; Ringsholt, M.; Høgdall, C.K.; Christensen, I.J.; Johansen, J.S.; Kjaer, S.K.; Blaakaer, J.; Ostenfeld-Møller, L.; Price, P.A.; Christensen, L.H. YKL-40 tissue expression and plasma levels in patients with ovarian cancer. BMC Cancer 2009, 9, 8.

37. Thöm, I.; Schmid, K.; Burkholder, I.; Johansen, J.S.; Bokemeyer, C.; Schumacher, U.; Laack, E. YKL-40 protein expression in pulmonary adenocarcinoma is not relation to prognosis. ASCO Ann. Meet. Proc. 2010, 28, Abstract e18129.

38. Bi, J.; Lau, S.H.; Lv, Z.L.; Xie, D.; Li, W.; Lai, Y.R.; Zhong, J.M.; Wu, H.Q.; Su, Q.; He, Y.L.; Zhan, W.H.; Wen, J.M.; Guan, X.Y. Overexpression of YKL-40 is an independent prognostic marker in gastric cancer. Hum. Pathol. 2009, 40, 1790-1797.

39. Huang, Y.; Prasad, M.; Lemon, W.J.; Hampel, H.; Wright, F.A.; Kornacker, K.; LiVolsi, V.; Frankel, W.; Kloos, R.T.; Eng, C.; Pellegata, N.S.; de la Chapelle, A. Gene expression in papillary thyroid carcinoma reveals highly consistent profiles. Proc. Natl. Acad. Sci. USA 2001, 98, 15044-15049.

40. Kim, S.H.; Das, K.; Noreen, S.; Coffman, F.; Hameed, M. Prognostic implications of immunohistochemically detected YKL-40 expression in breast cancer. World J. Surg. Oncol. 2007, 5, 17.

41. Qin, W.; Zhu, W.; Schlatter, L.; Miick, R.; Loy, T.S.; Atasoy, U.; Hewett, J.E.; Sauter, E.R. Increased expression of the inflammatory protein YKL-40 in precancers of the breast. Int. J. Cancer 2007, 121, 1536-1542.

42. Roslind, A.; Johansen, J.S.; Junker, N.; Nielsen, D.L.; Dzaferi, H.; Price, P.A.; Balslev, E. YKL40 expression in benign and malignant lesions of the breast: A methodologic study. Appl. Immunohistochem. Mol. Morphol. 2007, 15, 371-381.

43. Roslind, A.; Knoop, A.S.; Jensen, M.B.; Johansen, J.S.; Nielsen, D.L.; Price, P.A.; Balslev, E. YKL-40 protein expression is not a prognostic marker in patients with primary breast cancer. Breast Cancer Res. Treat. 2008, 112, 275-285.

44. Lau, S.H.; Sham, J.S.T.; Xie, D.; Tzang, C-H.; Tang, D.; Ma, N.; Hu, L.; Wang, Y.; Wen, J.-M.; Xiao, G.; Zhang, W.-M.; Lau, G.K.K.; Yang, M.; Guan, X.-Y. Clusterin plays an important role in hepatocellular carcinoma metastasis. Oncogene 2006, 25, 1242-1250.

45. Schunkert, H.; Samani, N.J. Elevated C-reactive protein in atherosclerosis - chicken or egg? Editorial. N. Engl. J. Med. 2008, 359, 1953-1955.

46. Nielsen, H.J.; Brünner, N.; Frederiksen, C.; Lomholt, A.F.; King, D.; Jørgensen, L.N.; Olsen, J.; Rahr, H.B.; Thygesen, K.; Hoyer, U.; Laurberg, S.; Christensen, I.J.; Danish-Australian Endoscopy Study Group on Colorectal Cancer Detection; Danish Colorectal Cancer Cooperative Group. Plasma tissue inhibitor of metalloproteinases-1 (TIMP-1): a novel biological marker in the detection of primary colorectal cancer. Protocol outlines of the Danish-Australian endoscopy study group on colorectal cancer detection. Scand. J. Gastroenterol. 2008, 43, 242-248. 
47. Johansen, J.S.; Christensen, I.J.; Price, P.A.; Nielsen, H.J.; The Danish Colorectal Cancer Study Group. Serum YKL-40 in risk assessment for colorectal cancer. A population based, prospective study of 4987 subjects at risk of colorectal cancer. ASCO Ann. Meet. Proc. 2008, 26, 212, Abstract 4136.

48. Jensen, B.V.; Johansen, J.S.; Price, P.A. High levels of serum HER-2/neu and YKL-40 independently reflect aggressiveness of metastatic breast cancer. Clin. Cancer Res. 2003, 9, 501-512.

49. Johansen, J.S.; Christensen, I.J.; Riisbro, R.; Greenall, M.; Han, C.; Price, P.A.; Smith, K.; Brünner, N.; Harris, A.L. High serum YKL-40 levels in patients with primary breast cancer is related to short recurrence free survival. Breast Cancer Res. Treat. 2003, 80, 15-21.

50. Coskun, U.; Yamac, D.; Gulbahar, O.; Sancak, B.; Karaman, N.; Ozkan, S. Locally advanced breast carcinoma treated with neoadjuvant chemotherapy: are the changes in serum levels of YKL-40, MMP-2 and MMP-9 correlated with tumor response?. Neoplasma 2007, 54, 348-352.

51. Yamac, D.; Ozturk, B.; Coskun, U.; Tekin, E.; Sancak, B.; Yildiz, R.; Atalay, C. Serum YKL-40 levels as a prognostic factor in patients with locally advanced breast cancer. Adv. Ther. 2008, 25, 801-809.

52. Cintin, C.; Johansen, J.S.; Christensen, I.J.; Price, P.A.; Sørensen, S.; Nielsen, H.J. Serum YKL-40 and colorectal cancer. Br. J. Cancer 1999, 79, 1494-1499.

53. Cintin, C.; Johansen, J.S.; Christensen, I.J.; Price, P.A.; Sørensen, S.; Nielsen, H.J. High serum YKL-40 level after surgery for colorectal carcinoma is related to short survival. Cancer 2002, 95, 267-274.

54. Jensen, B.V.; Spindler, K.-L.G.; Schou, J.V.; Christiansen, I.J.; Høgdall, E.; Nielsen, D.; Johannesen, H.H.; Pfeiffer, P.; Yilmaz, M.; Johansen, J.S. Association of YKL-40 levels in patient with metastatic colorectal cancer treated with third-line cetuximab and irinotecan with short survival. In 2010 Gastrointestinal Cancers Symposium, 22-24 January 2010, Orlando, FL, USA, Abstract 357.

55. Diefenbach, C.S.M.; Shah, Z.; Iasonos, A.; Barakat, R.R.; Levine, D.A.; Aghajanian, C.; Sabbatini, P.; Hensley, M.L.; Konner, J.; Tew, W.; Spriggs, D.; Fleisher, M.; Thaler, H.; Dupont, J. Preoperative serum YKL-40 is a marker for detection and prognosis of endometrial cancer. Gynecol. Oncol. 2007, 104, 435-442.

56. Thöm, I.; Andritzky, B.; Schuch, G.; Burkholder, I.; Edler, L.; Johansen, J.S.; Bokemeyer, C.; Schumacher, U.; Laack, E. Elevated pre-treatment serum concentration of YKL-40 - an independent prognostic biomarker for poor survival in patients with metastatic non-small cell lung cancer. Cancer 2010, doi: 10.1002/cncr.25196.

57. Schultz, N.A.; Johnsson, A.; Johansen, J.S.; Christensen, I.J.; Gunnlaugsson, A.; Byström, P.; Nygren, P.; Frödin, J.-E.; Wøjdemann, M.; Glimelius, B.; Berglund, Å. Plasma YKL-40 and IL-6, potential new biomarkers for pancreatic cancer and other upper gastrointestinal adenocarcinomas. BMC Cancer 2010, submitted.

58. Brasso, K.; Christensen, I.J.; Johansen, J.S.; Teisner, B.; Garnero, P.; Price, P.A.; Iversen, P. Prognostic value of PINP, bone alkaline phosphatase, CTX-I, and YKL-40 in patients with metastatic prostate carcinoma. Prostate 2006, 66, 503-513. 
59. Johansen, J.S.; Brasso, K.; Iversen, P.; Teisner, B.; Garnero, P.; Price, P.A.; Christensen, I.J. Changes of biochemical markers of bone turnover and YKL-40 following hormonal treatment for metastatic prostate cancer are related to survival. Clin. Cancer Res. 2007, 13, 3244-3249.

60. Kucur, M.; Isman, F.K.; Balci, C.; Onal, B.; Hacibekiroglu, M.; Ozkan, F. Serum YKL-40 levels and chitotriosidase activity as potential biomarkers in primary prostate cancer and benign prostatic hyperplasia. Urol. Oncol. 2008, 26, 47-52.

61. Høgdall, E.V.S.; Johansen, J.S.; Kjaer, S.K.; Price, P.A.; Christensen, L.; Blaakaer, J.; Bock, J.E.; Glud, E.; Høgdall, C.K. High plasma YKL-40 level in patients with ovarian cancer stage III is related to shorter survival. Oncol. Rep. 2003, 10, 1535-1538.

62. Dehn, H.; Høgdall, E.V.S.; Johansen, J.S.; Price, P.A.; Jørgensen, M.; Engelholm, S.A.A.; Høgdall, C.K. Plasma YKL-40, as a prognostic tumor marker in recurrent ovarian cancer. Acta Obstet. Gynecol. Scand. 2003, 82, 287-293.

63. Dupont, J.; Tanwar, M.K.; Thaler, H.T.; Fleisher, M.; Kauff, N.; Hensley, M.L.; Sabbatini, P.; Anderson, S.; Aghajanian, C.; Holland, E.C.; Spriggs, D.R. Early detection and prognosis of ovarian cancer using serum YKL-40. J. Clin. Oncol. 2004, 22, 3330-3339.

64. Grønlund, B.; Høgdall, E.V.S.; Christensen, I.J.; Johansen, J.S.; Nørgaard-Pedersen, B.; Engelholm, S.A.; Høgdall, C. Pre-treatment prediction of chemoresistance in second-line chemotherapy of ovarian carcinoma: value of serological tumor marker determination (tetranectin, YKL-40, CASA, CA125). Int. J. Biol. Markers 2006, 21, 141-148.

65. Chudecka-Glaz, A.; Górski, B.; Zielinska, D.; Blogowski, W.; Wojciechowska, I.; Bedner, R.; Rzepka-Górska, I. Serum YKL-40 levels in patients with ovarian cancer and women with BRCA1 gene mutation-comparison to CA 125 antigen. Eur. J. Gynaecol. Oncol. 2009, 30, 668-671.

66. Mitsuhashi, A.; Matsui, H.; Usui, H.; Nagai, Y.; Tate, S.; Unno, Y.; Hirashiki, K.; Seki, K.; Shozu, M. Serum YKL-40 as a marker for cervical adenocarcinoma. Ann. Oncol. 2009, 20, 71-77.

67. Johansen, J.S.; Roslind, A.; Palle, C.; Christensen, I.J.; Nielsen, H.J.; Price, P.A.; Nielsen, D.; Mosgaard, B. Serum YKL-40 levels in patients with cervical cancer are elevated compared to patients with cervical intraepithelial neoplasia and healthy controls. ASCO Ann. Meet. Proc. 2006, 24, 267, Abstract 5047.

68. Roslind, A.; Johansen, J.S.; Christensen, I.J.; Kiss, K.; Balslev, E.; Nielsen, D.L.; Bentzen, J.; Price, P.A.; Andersen, E. High serum levels of YKL-40 in patients with squamous cell carcinoma of the head and neck are associated with short survival. Int. J. Cancer 2008, 122, 857-863.

69. Castellano, I.; Mistrangelo, M.; Crudo, V.; Chiusa, L.; Lupo, R.; Ricardi, U.; Morino, M.; Mussa, A.; Cassoni, P. YKL-40 expression in anal carcinoma predicts shorter overall and disease-free survival. Histopathology 2009, 55, 238-240.

70. Junker, N.; Johansen, J.S.; Andersen, C.B.; Kristjansen, P.E.G. Expression of YKL-40 by peritumoral macrophages in human small cell lung cancer. Lung Cancer 2005, 48, 223-231.

71. Johansen, J.S.; Drivsholm, L.; Price, P.A.; Christensen, I.J. High serum YKL-40 level in patients with small cell lung cancer is related to early death. Lung Cancer 2004, 46, 333-340.

72. Geertsen, P.F.; Johansen, J.S.; von der Maase, H.; Jensen, B.V.; Price, P.A. High pretreatment serum level of YKL-40 is related to short survival in patients with advanced renal cell carcinoma 
treated with high-dose continuous intravenous infusion of interleukin-2. ASCO 2004. Ann. Meet. Proc. 2003, 22, 399, Abstract 1603.

73. Schmidt, H.; Johansen, J.S.; Gehl, J.; Geertsen, P.F.; Fode, K.; von der Maase, H. Elevated serum level of YKL-40 is an independent prognostic factor for poor survival in patients with metastatic melanoma. Cancer 2006, 106, 1130-1139.

74. Schmidt, H.; Johansen, J.S.; Sjoegren, P.; Christensen, I.J.; Sørensen, B.S.; Fode, K.; Larsen, J.; von der Maase, H. Serum YKL-40 predicts relapse-free and overall survival in patients with American Joint Committee on Cancer stage I and II melanoma. J. Clin. Oncol. 2006, 24, 798-804.

75. Krogh, M.; Christensen, I.J.; Bouwhuis, M.; Johansen, J.S.; Schmidt, H.; Hansson, J.; Aamdal, S.; Testori, A.; Eggermont, A.M.; Bastholt, L. Prognostic value of serum YKL-40 in stage IIB-III melanoma patients receiving adjuvant interferon therapy. ASCO Ann. Meet. Proc. 2010, Abstract 8587.

76. Junker, N.; Johansen, J.S.; Hansen, L.T.; Lund, E.L.; Kristjansen, P.E.G. Regulation of YKL-40 expression during genotoxic or microenvironmental stress in human glioblastoma cells. Cancer Sci. 2005, 96, 183-190.

77. Saidi, A.; Javerzat, S.; Bellahcene, A.; De Vos, J.; Bello, L.; Castronovo, V.; Deprez, M.; Loiseau, H.; Bikfalvi, A.; Hagedorn, M. Experimental anti-angiogenesis causes upregulation of genes associated with poor survival in glioblastoma. Int. J. Cancer 2008, 122, 2187-2198.

78. Krona, A.; Aman, P.; Orndal, C.; Josefsson, A. Oncostatin M-induced genes in human astrocytomas. Int. J. Oncol. 2007, 31, 1457-1463.

79. Lal, A.; Lash, A.E.; Altschul, S.F.; Velculescu, V.; Zhang, L.; McLendon, R.E.; Marra, M.A.; Prange, C.; Morin, P.J.; Polyak, K.; Papadopoulos, N.; Vogelstein, B.; Kinzler, K.W.; Strausberg, R.L.; Riggins, G.J. A public database for gene expression in human cancers. Cancer Res. 1999, 59, 5403-5407.

80. Markert, J.M.; Fuller, C.M.; Gillespie, G.Y.; Bubien, J.K.; McLean, L.A.; Hong, R.L.; Lee, K.; Gullans, S.R.; Mapstone, T.B.; Benos, D.J. Differential gene expression profiling in human brain tumors. Physiol. Genomics 2001, 5, 21-33.

81. Tanwar, M.K.; Gilbert, M.R.; Holland, E.C. Gene expression microarray analysis reveals YKL-40 to be a potential serum marker for malignant character in human glioma. Cancer Res. 2002, 62, 4364-4368.

82. Shostak, K.; Labunskyy, V.; Dmitrenko, V.; Malisheva, T.; Shamayev, M.; Rozumenko, V.; Zozulya, Y.; Zehetner, G.; Kavsan, V. HC gp-39 gene is upregulated in glioblastoma. Cancer Lett. 2003, 198, 203-210.

83. Colin, C.; Baeza, N.; Bartoli, C.; Fina, F.; Eudes, N.; Nanni, I.; Martin, P.-M.; Ouafik, L.; Figarella-Branger, D. Identification of genes differentially expressed in glioblastoma versus pilocytic astrocytoma using Suppression Subtractive Hybridization. Oncogene 2006, 25, 2818-2829.

84. Nigro, J.M.; Misra, A.; Zhang, L.; Smirnov, I.; Colman, H.; Griffin, C.; Ozburn, N.; Chen, M.; Pan, E.; Koul, D.; Yung, W.K.A.; Feuerstein, B.G.; Aldape, K.D. Integrated array-comparative genomic hybridization and expression array profiles identify clinically relevant molecular subtypes of glioblastoma. Cancer Res. 2005, 65, 1678-1686. 
85. Phillips, H.S.; Kharbanda, S.; Chen, R.; Forrest, W.F.; Soriano, R.H.; Wu, T.D.; Misra, A.; Nigro, J.M.; Colman, H.; Soroceanu, L.; Williams, P.M.; Modrusan, Z.; Feuerstein, B.G.; Aldape, K. Molecular subclasses of high-grade glioma predict prognosis, delineate a pattern of disease progression, and resemble stages in neurogenesis. Cancer Cell 2006, 9, 157-173.

86. Kroes, R.A.; Dawson, G.; Moskal, J.R. Focused microarray analysis of glyco-gene expression in human glioblastomas. J. Neurochem. 2007, 103, 14-24.

87. Ducray, F.; Idbaih, A.; de Reynies, A.; Bieche, I.; Thillet, J.; Mokhtari, K.; Lair, S.; Marie, Y.; Paris, S.; Vidaud, M.; Hoang-Xuan, K.; Delattre, O.; Delattre, J.-Y.; Sanson, M. Anaplastic oligodendrogliomas with 1p19q codeletion have a proneural gene expression profile. Mol. Cancer 2008, 7, 41.

88. Bhat, K.P.; Pelloski, C.E.; Zhang, Y.; Kim, S.H.; delaCruz, C.; Rehli, M.; Aldape, K.B. Selective repression of YKL-40 by NF-kappaB in glioma cell lines involves recruitment of histone deacetylase-1 and -2. FEBS Lett. 2008, 582, 3193-3200.

89. Pelloski, C.E.; Mahajan, A.; Maor, M.; Chang, E.L.; Woo, S.; Gilbert, M.; Colman, H.; Yang, H.; Ledoux, A.; Blair, H.; Passe, S.; Jenkins, R.B.; Aldape, K.D. YKL-40 expression is associated with poorer response to radiation and shorter overall survival in glioblastoma. Clin. Cancer Res. 2005, 11, 3326-3334.

90. Nutt, C.L.; Betensky, R.A.; Brower, M.A.; Batchelor, T.T.; Louis, D.N.; Stemmer-Rachamimow, A.O. YKL-40 is a differential diagnostic marker for histologic subtypes of high-grade gliomas. Clin. Cancer Res. 2005, 11, 2258-2264.

91. Pelloski, C.E.; Ballman, K.V.; Furth, A.F.; Zhang, L.; Lin, E.; Sulman, E.P.; Bhat, K.; McDonald, J.M.; Yung, W.K.A.; Colman, H.; Woo, S.Y.; Heimberger, A.B.; Suki, D.; Prados, M.D.; Chang, S.M.; Barker, F.G., II; Buckner, J.C.; James, D.; Aldape, K.. Epidermal growth factor receptor variant III status defines clinically distinct subtypes of glioblastoma. J. Clin. Oncol. 2007, 25, 2288-2294.

92. Rousseau, A.; Nutt, C.L.; Betensky, R.A.; Iafrate, J.; Han, M.; Ligon, K.L.; Rowitch, D.H.; Louis, D.N. Expression of oligodendroglial and astrocytic lineage markers in diffuse gliomas: use of YKL-40, ApoE, ASCL1, and NKX2-2. J. Neuropathol. Exp. Neurol. 2006, 65, 1149-1156.

93. Horbinski, C.; Wang, G.; Wiley, C.A. YKL-40 is directly produced by tumor cells and is inversely linked to EGFR in glioblastomas. Int. J. Clin. Exp. Pathol. 2010, 3, 226-237.

94. Hormigo, A.; Gu, B.; Karimi, S.; Riedel, E.; Panageas, K.S.; Edgar, M.A.; Tanwar, M.K.; Rao, J.S.; Fleisher, M.; DeAngelis, L.M.; Holland, E.C. YKL-40 and matrix metalloproteinase-9 as potential serum biomarkers for patients with high-grade gliomas. Clin. Cancer Res. 2006, 12, 5698-5704.

95. Antonelli, M.; Buttarelli, F.R.; Arcella, A.; Nobusawa, S.; Donofrio, V.; Oghaki, H.; Giangaspero, F. Prognostic significance of histological grading, p53 status, YKL-40 expression, and IDH1 mutations in pediatric high-grade gliomas. J. Neurooncol. 2010, doi: 10.1007/s11060010-0129-5.

96. Mylin, A.K.; Rasmussen, T.; Johansen J.S.; Knudsen, L.M.; Nørgaard, P.H.; Lenhoff, S.; Dahl, I.M.S.; Johnsen, H.E. Serum YKL-40 concentrations in newly diagnosed multiple myeloma patients and YKL-40 expression in malignant plasma cells. Eur. J. Hematol. 2006, 77, 416-424. 
97. Kirkpatrick, R.B.; Emery, J.G.; Connor, J.R.; Dodds, R.; Lysko, P.G.; Rosenberg, M. Induction and expression of human cartilage glycoprotein 39 in rheumatoid inflammatory and peripheral blood monocyte-derived macrophages. Exp. Cell Res. 1997, 237, 46-54.

98. Verhoeckx, K.C.M.; Bijlsma, S.; De Groene, E.M.; Witkamp, R.F.; van der Greef, F.; Rodenburg, R.J.T. A combination of proteomics, principal component analysis and transcriptomics is a powerful tool for the identification of biomarkes for macrophage maturation in the U937 cell line. Proteomics 2004, 4, 1014-1028.

99. Bergmann, O.J.; Johansen, J.S.; Klausen, T.W.; Mylin, A.K.; Kristensen, J.S.; Kjeldsen, E.; Johnsen, H.E. High serum concentration of YKL-40 is associated with short survival in patients with acute myeloid leukemia. Clin. Cancer Res. 2005, 11, 8644-8652.

100. Mylin, A.K.; Abildgaard, N.; Johansen, J.S.; Andersen, N.F.; Heickendorff, L.; Standal, T.; Gimsing, P.; Knudsen, L.M. High serum YKL-40 concentration is associated with severe bone disease in newly diagnosed multiple myeloma patients. Eur. J. Haematol. 2008, 80, 310-317.

101. Mylin, A.K.; Andersen, N.F.; Johansen, J.S.; Abildgaard, N.; Heickendorff, L.; Standal, T.; Gimsing, P.; Knudsen, L.M. Serum YKL-40 and bone marrow angiogenesis in multiple myeloma. Int. J. Cancer 2009, 124, 1492-1494.

102. Biggar, R,J.; Johansen, J.S.; Smedby, K.E.; Rostgaard, K.; Chang, E.T.; Adami, H-O.; Glimelius, B.; Molin, D.; Hamilton-Dutoit, S.; Melbye, M.; Hjalgrim, H. Serum YKL-40 and IL-6 levels in Hodgkin lymphoma. Clin. Cancer Res. 2008, 14, 6974-6979.

103. Lee, C.G.; Elias, J.A. Role of breast regression protein-39/YKL-40 in asthma and allergic responses. Allergy Asthma Immunol. Res. 2010, 2, 20-27.

104. Johansen, J.S.; Pedersen, A.N.; Schroll, M.; Jørgensen, T.; Pedersen, B.K.; Bruunsgaard, H. High serum YKL-40 level in a cohort of 80-years old is associated with increased risk of all-cause mortality. Clin. Exp. Immunol. 2008, 151, 260-266.

105. Gabay, C.; Kushner, I. Acute-phase proteins and other systemic responses to inflammation. $N$. Engl. J. Med. 1999, 340, 448-454.

106. Kushner, I.; Rzewnicki, D.; Samols, D. What does minor elevation of C-reactive protein signify? Am. J. Med. 2006, 119, 166, e17-28.

107. Rathcke, C.N.; Raymond, I.; Kistorp, C.; Hildebrandt, P.; Faber, J.; Vestergaard, H. Low grade inflammation as measured by levels of YKL-40: association with an increased overall and cardiovascular mortality rate in an elderly population. Int. J. Cardiol. 2009, doi: doi:10.1016/j.ijcard.2009.01.043.

108. Volck, B.; Price, P.A.; Johansen, J.S.; Sørensen, O.; Benfield, T.; Nielsen, H.J.; Calafat, J.; Borregaard, N. YKL-40, a mammalian member of the chitinase family, is a matrix protein of specific granules in human neutrophils. Proc. Assoc. Am. Phys. 1998, 110, 351-360.

109. Nordenbæk, C.; Johansen, J.S.; Junker, P.; Borregaard, N.; Sørensen, O.; Price, P.A. YKL-40, a matrix protein of specific granules in neutrophils, is elevated in serum of patients with communityacquired pneumonia requiring hospitalization. J. Infect. Dis. 1999, 180, 1722-1726.

110. Kronborg, G.; Østergaard, C.; Weis, N.; Nielsen, H.; Obel, N.; Pedersen, S.S.; Price, P.A.; Johansen, J.S. Serum level of YKL-40 is elevated in patients with Streptococcus pneumoniae bacteremia and is associated with the outcome of the disease. Scand. J. Infect. Dis. 2002, 34, 323-326. 
111. Hattori, N.; Oda, S.; Sadahiro, T.; Nakamura, M.; Abe, R.; Shinozaki, K.; Nomura, F.; Tomonaga, T.; Matsushita, K.; Kodera, Y.; Sogawa, K.; Satoh, M.; Hirasawa, H. YKL-40 identified by proteomic analysis as a biomarker of sepsis. Shock 2009,32, 393-400.

112. Johansen, J.S.; Krabbe, K.; Møller, K.; Pedersen, B.K. Circulating YKL-40 levels during human endotoxaemia. Clin. Exp. Immunol. 2005, 140, 343-348.

113. Østergaard, C.; Johansen, J.S.; Benfield, T.; Price, P.A.; Lundgren, J.D. YKL-40 is elevated in cerebrospinal fluid from patients with purulent meningitis. Clin. Diagn. Lab. Immun. 2002, 9, 598-604.

114. Boot, R.G.; van Achterberg, T.A.E.; van Aken, B.E.; Renkema, G.H.; Jacobs, M.J.H.M.; Aerts, J.M.F.G.; de Vries, C.J.M. Strong induction of members of the chitinase family of proteins in atherosclerosis. Chitotriosidase and human cartilage gp-39 expressed in lesion macrophages. Arterioscler. Thromb. Vasc. Biol. 1999, 19, 687-694.

115. Millis, A.J.T.; Hoyle, M.; Reich, E.; Mann, D.M. Isolation and characterization of a Mr = 38,000 protein from differentiating smooth muscle cells. J. Biol. Chem. 1985, 260, 3754-3761.

116. Millis, A.J.T.; Hoyle, M.; Kent, L. In vitro expression of a 38,000 dalton heparin-binding glycoprotein by morphologically differentiated smooth muscle cells. J. Cell Physiol. 1986, 127, 366-372.

117. Malinda, K.M.; Ponce, L.; Kleinman, H.K.; Shackelton, L.M.; Millis, A.J.T. Gp38k, a protein synthesized by vascular smooth muscle cells, stimulates directional migration of human umbilical vein endothelial cells. Exp. Cell Res. 1999, 250, 168-173.

118. Nishikawa, K.C.; Millis, A.J.T. Gp38k (CHI3L1) is a novel adhesion and migration factor for vascular cells. Exp. Cell Res. 2003, 287, 79-87.

119. Johansen, J.S.; Baslund, B.; Garbarsch, C.; Hansen, M.; Stoltenberg, M.; Lorenzen, I.; Price, P.A. YKL-40 in giant cells and macrophages from patients with giant cell arteritis. Arthritis Rheum. 1999, 42, 2624-2630.

120. Nøjgaard, C.; Høst, N.B.; Christensen, I.J.; Poulsen, S.H.; Egstrup, K.; Price, P.A.; Johansen, J.S. Serum levels of YKL-40 increases in patients with acute myocardial infarction. Coron. Artery Dis. 2008, 19, 257-263.

121. Wang, Y.; Ripa, R.S.; Johansen, J.S.; Gabrielsen, A.; Steinbrüchel, D.A.; Friis, T.; Bindslev, L.; Haack-Sørensen, M.; Jørgensen, E.; Kastrup, J. YKL-40 a new biomarker in patients with acute coronary syndrome or stable coronary artery disease. Scand. Card. J. 2008, 42, 295-302.

122. Kucur, M.; Isman, F.K.; Karadag, B.; Vural, V.A.; Tavsanoglu, S. Serum YKL-40 levels in patients with coronary artery disease. Coron. Artery Dis. 2007, 18, 391-396.

123. Zheng, J.L.; Lu, L.; Hu, J.; Zhang, R.Y.; Zhang, Q., Chen, Q.J.; Shen, W.F. Increased serum YKL-40 and C-reactive protein levels are associated with angiographic lesion progression in patients with coronary artery disease. Atherosclerosis 2010, 210, 590-595.

124. Henningsen, K.M.; Therkelsen, S.K.; Johansen, J.S.; Bruunsgaard, H.; Svendsen, J.H. Plasma YKL-40, a new biomarker for artrial fibrillation? Europace 2009, 11, 1032-1036.

125. Henningsen, K.M.; Nilsson, B.; Johansen, J.S.; Chen, X.; Pehrson, S.; Svendsen, J.H. Plasma YKL-40 is elevated in patients with recurrent atrial fibrillation after catheter ablation. Inflamm. Res. 2010, 59, 463-469. 
126. Kastrup, J.; Johansen, J.S.; Winkel, P.; Hansen, J.F.; Hildebrandt, P.; Jensen, G.B.; Jespersen, C.M.; Kjøller, E.; Kolmos H.J.; Lind, I.M.; Nielsen, H.; Gluud, C.; The CLARICOR Trial Group. High serum concentration of YKL-40 in patients with stable coronary artery disease is associated with increased risk of myocardial infarction, cardiovascular death and all-cause mortality. Eur. Heart J. 2009, 30, 1066-1072.

127. Rathcke, C.N.; Kistorp, C.; Raymond, I.; Hildebrandt, P.; Gustafsson, F.; Lip, G.Y.; Faber, J.; Vestergaard, H. Plasma YKL-40 levels are elevated in patients with chronic heart failure. Scand. Cardiovasc. J. 2009, Dec 4 Epub ahead of print.

128. Hedegaard, A.; Ripa, R.S.; Johansen, J.S.; Jørgensen, E.; Kastrup, J. Plasma YKL-40 and recovery of left ventricular function after acute myocardial infarction. Scand. J. Clin. Lab. Invest. 2010, 70, 80-86.

129. Rathcke, C.N.; Johansen, J.S.; Vestergaard, H. YKL-40, a biomarker of inflammation, is elevated in patients with type 2 diabetes and is related to insulin resistance. Inflamm. Res. 2006, 55, 53-59.

130. Nielsen, A.R.; Erikstrup, C.; Johansen, J.S.; Fischer, C.P.; Plomgaard, P.; Krogh-Madsen, R.; Taudorf, S.; Mortensen, O.H.; Petersen, A.M.W.; Lindegaard, B.; Pedersen, B.K. Plasma YKL40: a BMI-independent marker of type 2 diabetes. Diabetes 2008, 57, 3078-3082.

131. Rathcke, C.N.; Persson, F.; Tarnow, L.; Rossing, P.; Vestergaard, H. YKL-40, a marker of inflammation and endothelial dysfunction, is elevated in patients with type 1 diabetes and increases with levels of albuminuria. Diabetes Care 2009, 32, 323-328.

132. Rathcke, C.N.; Vestergaard, H. YKL-40 - an emerging biomarker in cardiovascular disease and diabetes. Cardiovasc. Diabetol. 2009, 8, 61.

133. Volck, B.; Johansen, J.S.; Stoltenberg, M.; Garbarsch, C.; Price, P.A.; Østergaard, M.; Østergaard, K.; Løvgreen-Nielsen, P.; Sonne-Holm, S.; Lorenzen, I. Studies on YKL-40 in knee joints of patients with rheumatoid arthritis and osteoarthritis. Involvement of YKL-40 in the joint pathology. Osteoarthr. Cartil. 2001, 9, 203-214.

134. Johansen, J.S.; Olee, T.; Price, P.A.; Hashimoto, S.; Ochs, R.L.; Lotz, M. Regulation of YKL-40 production by human articular chondrocytes. Arthritis Rheum. 2001, 44, 826-837.

135. Nyirkos, P.; Golds, E.E. Human synovial cells secrete a 39 kDa protein similar to a bovine mammary protein expressed during the non-lactating period. Biochem. J. 1990, 268, 265-268.

136. Dasuri, K.; Antonovici, M.; Chen, K.; Wong, K.; Standing, K.; Ens, W.; El-Gabalawy, H.; Wilkins, J.A. The synovial proteome: analysis of fibroblast-like synoviocytes. Arthritis Res. Ther. 2004, 6, R161-168.

137. Baeten, D.; Boots, A.M.H.; Steenbakkers, P.G.A.; Elewaut, D.; Bos, E.; Verheijden G.F.M.; Verbruggen, G.; Miltenburg, A.M.M.; Rijnders, A.W.M.; Veys, E.M.; de Keyser, F. Human cartilage gp-39+, CD16+ monocytes in peripheral blood and synovium.Correlation with joint destruction in rheumatoid arthritis. Arthritis Rheum. 2000, 43, 1233-1243.

138. Belge, K.U.; Dayyani, F.; Horelt, A.; Siedlar, M.; Frankenberger, M.; Frankenberger, B.; Espevik, T.; Ziegler-Heitbrock, L. The proinflammatory CD14+CD16+DR++ monocytes are a major source of TNF. J. Immunol. 2002, 168, 3536-3542.

139. Johansen, J.S.; Stoltenberg, M.; Hansen, M., Florescu, A.; Hørslev-Petersen, K.; Lorenzen, I.; Price, P.A. Serum YKL-40 concentrations in patients with rheumatoid arthritis: relation to disease activity. Rheumatology 1999, 38, 618-626. 
140. Johansen, J.S.; Kirwan, J.R.; Price, P.A.; Sharif, M. Serum YKL-40 concentrations in patients with early rheumatoid arthritis: relation to joint destruction. Scand. J. Rheumatol. 2001, 30, 297-304.

141. Harvey, S.; Whaley, J.; Eberhardt, K. The relationship between serum levels of YKL-40 and disease progression in patients with early rheumatoid arthritis. Scand. J. Rheumatol. 2000, 29, 391-393.

142. Vos, K.; Steenbakkers, P.; Miltenburg, A.M.M.; Bos, E.; van den Heuvel, M.V.; van Hogezand, R.A.; de Vries, R.R.P.; Breedveld, F.C.; Boots, A.M.H. Raised human cartilage glycoprotein-39 plasma levels in patients with rheumatoid arthritis and other inflammatory conditions. Ann. Rheum. Dis. 2000, 59, 544-548.

143. Combe, B.; Dougados, M.; Goupille, P.; Cantagrel, A.; Eliaou, J.F.; Sibilia, J.; Meyer, O.; Sany, J.; Daures, J.-P.; Dubois, A. Prognostic factors for radiographic damage in early rheumatoid arthritis: a multiparameter prospective study. Arthritis Rheum. 2001, 44, 1736-1743.

144. Peltomaa, R.; Paimela, L.; Harvey, S.; Helve, T.; Leirisalo-Repo, M. Increased level of YKL-40 in sera from patients with early rheumatoid arthritis: a new marker for disease activity. Rheumatol. Int. 2001, 20, 192-196.

145. Matsumoto, T.; Tsurumoto, T. Serum YKL-40 levels in rheumatoid arthritis: correlations between clinical and laboratory parameters. Clin. Exp. Rheumatol. 2001, 19, 655-660.

146. Knudsen, L.S.; Østergaard, M.; Baslund, B.; Narvestad, E.; Petersen, J.; Nielsen, H.J.; Ejbjerg, B.J.; Szkudlarek, M.; Johansen, J.S. Plasma IL-6, plasma VEGF and serum YKL-40: relationship with disease activity and radiographic progression in rheumatoid arthritis patients treated with infliximab and methotrexate. Scand. J. Rheumatol. 2006, 35, 489-491.

147. Knudsen, L.S.; Klarlund, M.; Skjødt, H.; Jensen, T.; Østergaard, M.; Jensen, K.E.; Hansen, M.S.; Hetland, M.L.; Nielsen, H.J.; Johansen, J.S. Biomarkers of inflammation in patients with unclassified polyarthritis and early rheumatoid arthritis. Relationship to disease activity and radiographic outcome. J. Rheumatol. 2008, 35, 1277-1287.

148. Sharif, M.; Granell, R.; Johansen, J.S.; Clarke, S.; Elson, C.; Kirwan, J.R. Serum cartilage oligomeric matrix protein and other biomarker profiles in tibiofemoral and patellofemoral osteoarthritis of the knee. Rheumatology 2006, 5, 522-526.

149. Chupp, G.L.; Lee, C.G.; Jarjour, N.; Shim, Y.M.; Holm, C.T.; He, S.; Dziura, J.D.; Reed, J.; Coyle, A.J.; Kiener, P.; Cullen, M.; Grandsaigne, M.; Dombret, M.-C.; Aubier, M.; Pretolani, M.; Elias, J.A. A chitinase-like protein in the lung and circulation of patients with severe asthma. N. Engl. J. Med. 2007, 357, 2016-2027.

150. Letuve, S.; Kozhich, A.; Arouche, N.; Grandsaigne, M.; Reed, J.; Dombret, M.-C.; Kiener, P.A.; Aubier, M.; Coyle, A.J.; Pretolani, M. YKL-40 is elevated in patients with chronic obstructive pulmonary disease and activates alveolar macrophages. J. Immunol. 2008, 181, 5167-5173.

151. Johansen, J.S.; Milman, N.; Hansen, M.; Garbarsch, C.; Price, P.A.; Graudal, N. Increased serum YKL-40 in patients with pulmonary sarcoidosis. A potential marker of disease activity? Respir. Med. 2005, 99, 396-402.

152. Kuepper, M.; Bratke, K.; Virchow, J.C. Chitinase-like protein and asthma. N. Engl. J. Med. 2008, 358, 1073-1075. 
153. Montagna, G.L.; D’Angelo, S.; Valentini, G. Cross-sectional evaluation of YKL-40 serum concentrations in patients with systemic sclerosis. Relationship with clinical and serological aspects of disease. J. Rheumatol. 2003, 30, 2147-2151.

154. Nordenbæk, C.: Johansen, J.S.; Halberg, P.; Wiik, A.; Garbarsch, C.; Ullman, S.; Price, P.A.; Jacobsen, S. High serum levels of YKL-40 in patients with systemic sclerosis are associated with pulmonary involvement. Scand. J. Rheumatol. 2005, 34, 293-297.

155. Ober, C.; Chupp, G.L. The chitinase and chitinase-like proteins: a review of genetic and functional studies in asthma and immune-mediated diseases. Curr. Opin. Allergy Clin. Immunol. 2009, 9, 401-408.

156. Koutroubakis, I.E.; Petinaki, E.; Dimoulios, P.; Vardas, E.; Roussomoustakaki, M.; Maniatis, A.N.; Kouroumalis, E.A. Increased serum levels of YKL-40 in patients with inflammatory bowel disease. Int. J. Colorectal Dis. 2003, 18, 254-259.

157. Punzi, L.; Podswiadek, M.; D’Inca, R.; Zaninotto, M.; Bernardi, D.; Plebani, M.; Sturniolo, G.C. Serum human cartilage glycoprotein 39 as a marker of arthritis associated with inflammatory bowel disease. Ann. Rheum. Dis. 2003, 62, 1224-1226.

158. Vind, I.; Johansen, J.S.; Price, P.A.; Munkholm, P. Serum YKL-40, a potential new marker of disease activity in patients with inflammatory bowel disease. Scand. J. Gastroenterol. 2003, 38, 599-605.

159. Erzin, Y.; Uzun, H.; Karatas, A.; Celik, A.F. Serum YKL-40 as a marker of disease activity and stricture formation in patients with Crohn's disease. J. Gastroenterol. Hepatol. 2008, 23, e357-362.

160. Johansen, J.S.; Møller, S.; Price, P.A.; Bendtsen, F.; Junge, J.; Garbarsch, C.; Henriksen, J.H. Plasma YKL-40: a new potential marker of fibrosis in patients with alcoholic cirrhosis? Scand. J. Gastroenterol. 1997, 32, 582-590.

161. Johansen, J.S.; Christoffersen, P.; Møller, S.; Price, P.A.; Henriksen, J.H.; Garbarsch, C.; Bendtsen, F. Serum YKL-40 is increased in patients with hepatic fibrosis. J. Hepatol. 2000, 32, 911-920.

162. Berres, M.L.; Papen, S.; Pauels, K.; Schmitz, P.; Zaldivar, M.M.; Hellerbrand, C.; Mueller, T.; Berg, T.; Weiskirchen, R.; Trautwein, C.; Wasmuth, H.E. A functional variation in CHI3L1 is associated with severity of liver fibrosis and YKL-40 serum levels in chronic hepatitis C infection. J. Hepatol. 2009, 50, 370-376.

163. Nøjgaard, C.; Johansen, J.S.; Christensen, E.; Skovgaard, L.T.; Price, P.A.; Becker, U.; The EMALD Group. Serum levels of YKL-40 and PIIINP as prognostic markers in patients with alcoholic liver disease. J. Hepatol. 2003, 39, 179-186.

164. Tran, A.; Benzaken, S.; Saint-Paul, M.C.; Guzman-Granier, E.; Hastier, P.; Pradier, C.; Barjoan, E.M.; Demuth, N.; Longo, F.; Rampal, P. Chondrex (YKL-40), a potential new serum fibrosis marker in patients with alcoholic liver disease. Eur. J. Gastroenterol Hepatol. 2000, 12, 989-993.

165. Nøjgaard, C.; Johansen, J.S.; Krarup, H.B.; Holten-Andersen, M.; Møller, A.; Bendtsen, F.; Danish Viral Hepatitis Study Group. Effect of antiviral therapy on markers of fibrogenesis in patients with chronic hepatitis C. Scand. J. Gastroenterol. 2003, 38, 659-665.

166. Nunes, D.; Fleming, C.; Offner, G.; O’Brien, M.; Tumilty, S.; Fix, O.; Heeren, T.; Koziel, M.; Graham, C.; Craven, D.E.; Stuver, S.; Horsburgh, C.R., Jr. HIV infection does not affect the performance of noninvasive markers of fibrosis for the diagnosis of hepatitis $\mathrm{C}$ virus-related liver disease. J. Acquir. Immune. Defic. Syndr. 2005, 40, 538-544. 
167. Zheng, M.; Cai, W.M.; Zhao, J.K.; Zhu, S.M.; Liu, R.H. Determination of serum levels of YKL-40 and hyaluronic acid in patients with hepatic fibrosis due to schistosomiasis japonica and appraisal of their clinical value. Acta Trop. 2005, 96, 148-152.

168. Kamal, S.M.; Turner, B.; He, Q.; Rasenack, J.; Bianchi, L.; Tawil, A.A.; Nooman, A.; Massoud, M.; Koziel, M.J.; Afdhal, N.H. Progression of fibrosis in hepatitis C with and without schistosomiasis: correlation with serum markers of fibrosis. Hepatology 2006, 43, 771-779.

169. Alexander, J.; Tung, B.Y.; Croghan, A.; Kowdley, K.V. Effect of iron depletion on serum markers of fibrogenesis, oxidative stress and serum liver enzymes in chronic hepatitis C: results of a pilot study. Liver Int. 2007, 27, 268-273.

170. Esmat, G.; Metwally, M.; Zalata, K.R.; Gadalla, S.; Abdel-Hamid, M.; Abouzied, A.; Shaheen, A.A.; El-Raziky, M.; Khatab, H.; El-Kafrawy, S.; Mikhail, N.; Magder, L.S.; Afdhal, N.H.; Strickland, G.T. Evaluation of serum biomarkers of fibrosis and injury in Egyptian patients with chronic hepatitis C. J. Hepatol. 2007, 46, 620-627.

171. Fontana, R.J.; Goodman, Z.D.; Dienstag, J.L.; Bonkovsky, H.L.; Naishadham, D.; Sterling, R.K.; Su, G.L.; Ghosh, M.; Wright, E.C.; the HALT-C Trial Group. Relationship of serum fibrosis markers with liver fibrosis stage and collagen content in patients with advanced chronic hepatitis C. Hepatology 2008, 47, 789-798.

172. Fontana, R.J.; Bonkovsky, H.L.; Naishadham, D.; Dienstag, J.L.; Sterling, R.K.; Lok, A.S.; Su, G.L.; Halt-C Trial Group. Serum fibrosis marker levels decrease after successful antiviral treatment in chronic hepatitis C patients with advanced fibrosis. Clin. Gastroenterol. Hepatol. 2009, 7, 219-226.

173. Lebensztejn, D.M.; Skiba, E.; Werpachowska, I.; Sobaniec-Lotowska, M.E.; Kaczmarksi, M. Serum level of YKL-40 does not predict advanced liver fibrosis in children with chronic hepatitis B. Adv. Med. Sci. 2007, 52, 120-124.

174. Pungpapong, S.; Nunes, D.P.; Krishna, M.; Nakhieh, R.; Chambers, K.; Ghabril, M.; Dickson, R.C.; Hughes, C.B.; Steers, J.; Nguyen, J.H.; Keaveny, A.P. Serum fibrosis markers can predict rapid fibrosis progression after liver transplantation for hepatitis C. Liver Transpl. 2008, 14, 1294-1302.

175. Mehta, P.; Ploutz-Snyder, R.; Nandi, J.; Rawlins, S.R.; Sanderson, S.O.; Levine, R.A. Diagnostic accuracy of serum hyaluronic acid, FIBROSpect II, and YKL-40 for discriminating fibrosis stages in chronic hepatitis C. Am. J. Gastroenterol. 2008, 103, 928-936.

176. Schiavon, L.L.; Narciso-Schiavon, J.L.; Carvalho-Filho, R.J.; Sampaio, J.P.; Medina-Pestana, J.O.; Lanzoni, V.P.; Silva, A.E.; Ferraz, M.L. Serum levels of YKL-40 and hyaluronic acid as non-invasive markers of liver fibrosis in haemodialysis patients with chronic hepatitis $\mathrm{C}$ virus infection. J. Viral. Hepat. 2008, 15, 666-674.

177. Lee, K.G.; Seo, Y.S.; An, H.; Um, S.H.; Jung, E.S.; Keum, B.; Yim, H.J.; Jeen, Y.T.; Chun, H.J.; Kim, C.D.; Ryu, H.S. Usefulness of non-invasive markers for predicting liver cirrhosis in patients with chronic hepatitis B. J. Gastroenterol. Hepatol. 2010, 25, 94-100.

178. Schiavon, L.L.; Carvalho-Filho, R.J.; Narciso-Schiavon, J.L.; Medina-Pestana, J.O.; Lanzoni, V.P.; Ferraz, M.L.; Silva, A.E. YKL-40 and hyaluronic acid (HA) as noninvasive markers of liver fibrosis in kidney transplant patients with HCV chronic infection. Scand. J. Gastroenterol. 2010, 45, 615-622. 
179. Recklies, A.D.; White, C.; Ling, H. The chitinase 3-like protein human cartilage 39 (HC-gp39) stimulates proliferation of human connective-tissue cells and activates both extracellular signalregulated kinase-and protein kinase B-mediated signalling pathways. Biochem. J. 2002, 365, 119-126.

180. Recklies, A.D.; Ling, H.; White, C.; Bernier, S.M. Inflammatory cytokines induce production of CHI3L1 by articular chondrocytes. J. Biol. Chem. 2005, 280, 41213-41221.

181. Ling, H.; Recklies, A.D. The chitinase 3-like protein human cartilage glycoproein 39 inhibits cellular responses to the inflammatory cytokines interleukin-1 and tumor necrosis factor-alpha. Biochem. J. 2004, 380, 651-659.

182. Biosselier, B.; Marie, Y.; El Hallani, S.; Kaloshi, G.; Iershov, A.; Kavsan, V.; Psimaras, D.; Thillet, J.; Hoang-Xuan, K.; Delattre, J.Y.; Sanson, M. No association of $(-131 \mathrm{C} \rightarrow \mathrm{G})$ variant of CHI3L1 gene with risk of glioblastoma and prognosis. J. Neurooncol. 2009, 94, 169-172.

183. Ober, C.; Tan, Z.; Sun, Y.; Possick, J.D.; Pan, L.; Nicolae, R.; Radford, S.; Parry, R.R.; Heinzmann, A.; Deichmann, K.A.; Lester, L.A.; Gern, J.E.; Lemanske, R.F., Jr.; Nicolae, D.L.; Elias, J.A.; Chupp, G.L. Effect of variation in CHI3L1 on serum YKL-40 level, risk of asthma, and lung function. N. Engl. J. Med. 2008, 358, 1682-1691.

184. Zhao, X.; Tang, R.; Gao, B.; Shi, Y.; Zhou, J.; Guo, S.; Zhang, J.; Wang, Y.; Tang, W.; Meng, J.; Li, S.; Wang, H.; Ma, G.; Lin, C.; Xiao, Y.; Feng, G.; Lin, Z.; Zhu, S.; Xing, Y.; Sang, H.; St. Clair, D.; He, L. Functional variants in the promoter region of Chitinase 3-Like 1 (CHI3L1) and susceptibility to schizophrenia. Am. J. Hum. Genet. 2007, 80, 12-18.

185. Yang, M.S.; Morris, D.W.; Donohoe, G.; Kenny, E., O’Dushalaine, C.T.; Schwaiger, S.; Nangle, J.M.; Clarke, S.; Scully, P.; Quinn, J.; Meagher, D.; Baldwin, P.; Crumlish, N.; O’Callaghan, E.; Waddington, J.L.; Gill, M.; Corvin, A. Chitinase-3-like 1 (CHI3L1) gene and schizophrenia: genetic association and a potential functional mechanism. Biol. Psychiatry 2008, 64, 98-103.

186. Ohi, K.; Hashimoto, R.; Yasuda, Y.; Yoshida, T.; Takahashi, H.; Iike, N.; Iwase, M.; Kamino, K.; Ishii, R.; Kazui, H.; Fukumoto, M.; Takamura, H.; Yamamori, H.; Azechi, M.; Ikezawa, K.; Tanimukai, H.; Tagami, S.; Morihara, T.; Okochi, M.; Yamada, K.; Numata, S.; Ikeda, M.; Tanaka, T.; Kudo, T.; Ueno, S.; Yoshikawa, T.; Ohmori, T.; Iwata, N.; Ozaki, N.; Takeda, M. The chitinase 3-like 1 gene and schizophrenia: evidence from a multi-center case-control study and meta-analysis. Schizophr. Res. 2010, 116, 126-132.

187. Srivastava, S.K.; Antal, P.; Gal, J.; Hullam, G.; Semsei, A.F.; Nagy, G.; Falus, A.; Buzas, E.I. Lack of evidence for association of two functional SNPs of CHI3L1 gene (HC-gp39) with rheumatoid arthritis. Rheumatol. Int. 2010, doi: 10.1007/s00296-010-1396-3.

188. Kruit, A.; Grutters, J.C.; Ruven, H.J.T.; van Moorsel, C.C.; van den Bosch, J.M. A CHI3L1 gene polymorphism is associated with serum levels of YKL-40, a novel sarcoidosis marker. Respir. Med. 2007, 101, 1563-1571.

189. Rathcke, C.N.; Holmkvist, J.; Jørgensen, T.; Borch-Johnsen, K.; Hansen, T.; Pedersen, O.B.; Vestergaard, H. Variation in CHI3LI in relation to type 2 diabetes and related quantitative traits. PloS One 2009, 4, e5469.

190. Rathcke, C.N.; Holmkvist, J.; Husmoen, L.L.; Hansen, T.; Pedersen, O.; Vestergaard, H.; Linneberg, A. Association of polymorphisms of the CHI3L1 gene with asthma and atopy: a populations-based study of 6514 Danish adults. PloS One 2009, 4, e6106. 
191. Krause, S.W.; Rehli, M.; Kreutz, M.; Schwarzfisher, L.; Paulauski, J.D.; Andreesen, R. Differential screening identifies genetic markers of monocyte to macrophage maturation. J. Leukocyte Biol. 1996, 60, 540-545.

192. Hashimoto, S.; Suzuki, T.; Dong, H.Y.; Yamazaki, N.; Matsushima, K. Serial analysis of gene expression in human monocytes and macrophages. Blood 1999, 94, 837-844.

193. Suzuki, T.; Hashimoto, S.; Toyoda, N.; Nagai, S.; Yamazaki, N.; Dong, H.Y.; Sakai, J.; Yamashita, T.; Nukiwa, T.; Matsushima, K. Comprehensive gene expression profile of LPSstimulated human monocytes by SAGE. Blood 2000, 96, 2584-2591.

194. Benz, K.; Breit, S.; Lukoschek, M.; Mau, H.; Richter, W. Molecular analysis of expansion, differentiation, and growth factor treatment of human chondrocytes identifies differentiation markers and growth-related genes. Biochem. Biophys. Res. Commun. 2002, 293, 284-292.

195. Stokes, D.G.; Liu, G.; Coimbra, I.B.; Piera-Velazquez, S.; Crowl, R.M.; Jimenez, S.A. Assessment of the gene expression profile of differentiated and dedifferentiated human fetal chondrocytes by microarray analysis. Arthritis Rheum. 2002, 46, 404-419.

196. Imabayashi, H.; Mori, T.; Gojo, S.; Kioyono, T.; Sugiyama, T.; Irie, R.; Isoga, T.; Hata, J.; Toyama, Y.; Umezawa, A. Redifferentiation of dedifferentiated chondrocytes and chondrogenesis of human bone marrow stromal cells via chondrosphere formation with expression profiling by large-scale cDNA analysis. Exp. Cell Res. 2003, 288, 35-50.

197. Junker, N.; Johansen, J.S.; Kristjansen, P.E.G.; Price, P.A. Monoclonal antibody therapy against YKL-40 delays growth in glioblastoma xenografts. In American Association for Cancer Research Annual Meeting: Proceedings 2007, 14-18 April 2007, Los Angeles, CA, USA, Abstract 4099.

198. Pelloski, C.E.; Lin, E.; Zhang, L.; Yung, W.K.A.; Colman, H.; Liu, J.-L.; Woo, S.Y.; Heimberger, A.B.; Suki, D.; Prados, M.; Chang, S.; Barker, F.G., III; Fuller, G.N.; Aldape, K.D. Prognostic associations of activated mitogen-activated protein kinase and akt pathways in glioblastoma. Clin. Cancer Res. 2006, 12, 3935-3941.

199. Lee, C.G.; Haartl, D.; Lee, G.R.; Koller, B.; Matsuura, H.; Da Silva, C.A.; Sohn, M.H.; Cohn, L.; Homer, R.J.; Kozhich, A.A.; Humbles, A.; Keaney, J.; Coyle, A.; Chupp, G.; Reed, J.; Flavell, R.A.; Elias, J.A. Role of breast regression protein 39 (BRP-39)/chitinase 3-like-1 in Th2 and IL12-induced tissue responses and apoposis. J. Exp. Med. 2009, 206, 1149-1166.

200. Shao, R.; Hamel, K.; Petersen, L.; Cao, Q.J.; Arenas, R.B.; Bigelow, C.; Bentley, B.; Yan, W. YKL-40, a secreted glycoprotein, promotes tumor angiogenesis. Oncogene 2009, 28, 4456-4468.

201. Hillen, F.; Griffioen, A.W. Tumor vascularization: sprouting angiogenesis and beyond. Cancer Metastasis Rev. 2007, 26, 489-502.

202. Mizoguchi, E. Chitinase 3-like-1 exacerbates intestinal inflammation by enhancing bacterial adhesion and invasion in colonic epithelial cells. Gastroenterology 2006, 130, 398-411.

203. Mizoguchi, E.; Mizoguchi, A. Is the sugar always sweet in intestinal inflammation? Immunol. Res. 2007, 37, 47-60.

204. Kawada, M.; Chen, C.C.; Arihiro, A.; Nagatani, K.; Watanabe, T.; Mizoguchi, E. Chitinase 3like-1 enhances bacterial adhesion to colonic epithelial cells through the interaction with bacterial chitin-binding protein. Lab. Invest. 2008, 88, 883-895.

205. Verheiden, G.F.M.; Rijnders, A.W.M.; Bos, E.; Coenen de-Roo, C.J.J.; van Staveren, C.J.; Miltenburg, A.M.M.; Meijerink, J.H.; Elewaut, D.; Keyser, F.; Veys, E.; Boots, A.M.H. Human 
cartilage glycoprotein-39 as a candidate autoantigen in rheumatoid arthritis. Arthritis Rheum. 1997, 40, 1115-1125.

206. Cope, A.P.; Patel, S.D.; Hall, F.; Congia, M.; Hubers, H.A.J.M.; Verheijden, G.F.; Boots, A.M.H.; Menon, R.; Trucco, M.; Rijnders, A.V.M.; Sønderstrup, G. T cell responses to a human cartilage autoantigen in the context of rheumatoid arthritis-associated and nonassociated HLADR4 alleles. Arthritis Rheum. 1999, 42, 1497-1507.

207. Joosten, L.A.B.; Coenen de-Roo, C.J.J.; Helsen, M.M.A.; Lubberts, E.; Boots, A.M.H.; van der Berg, W.B.; Miltenburg, A.M.M. Induction of tolerance with intranasal administration of human cartilage gp-39 in DBA/1 mice. Arthritis Rheum. 2000, 43, 645-655.

208. Vos, K.; Miltenburg, A.M.M.; van Meijgaarden, K.E.; van den Heuvel, M.; Elferink, D.G.; van Galen, P.J.M.; van Hogezand, R.A.; van Vilet-Daskalopoulou, E.; Ottenhoff, T.H.M.; Breedveld, F.C.; Boots, A.M.H.; de Vries, R.R.P. Cellular immune response to human cartilage glycoprotein39 (HC gp-39)-derived peptides in rheumatoid arthritis and other inflammatory conditions. Rheumatology 2000, 39, 1326-1331.

209. Patil, N.S.; Hall, F.C.; Drover, S.; Spurrell, D.R.; Bos, E.; Cope, A.P.; Sonderstrup, G.; Mellins, E.D. Autoantigenic HCgp39 epitopes are presented by the HLA-DM-dependent presentation pathway in human B cells. J. Immunol. 2001, 166, 33-41.

210. Kavanaugh, A.; Genovese, M.; Baughman, J.; Kivitz, A.; Bulpitt, K.; Olsen, N.; Weisman, M.; Matteson, E.; Furst, D.; van Vollenhoven, R.; Anderson, J.; Cohen, S.; Wei, N.; Meijerink, J.; Jacobs, C.; Mocci, S. Allele and antigen-specific treatment of rheumatoid arthritis: a double blind, placebo controlled phase 1 trial. J. Rheumatol. 2003, 30, 449-454.

211. Steenbakkers, P.G.A.; Baeten, D.; Rovers, E.; Veys, E.M.; Rijnders, A.W.M.; Meijerink, J.; Keyser, F.D.; Boots. A.M.H. Localization of MHC Class II/human cartilage glycoprotein-39 complexes in synovia of rheumatoid arthritis patients using complex-specific monoclonal antibodies. J. Immunol. 2003, 170, 5719-5727.

212. Dickey, B.F. Editorial. Exoskeletons and exhalation. N. Engl. J. Med. 2007, 357, 2082-2084.

213. Dvorak, H.F. Tumors: wounds that do not heal. Similarities between tumor stroma generation and wound healing. N. Engl. J. Med. 1986, 315, 1650-1659.

214. Balkwill, F.; Mantovani, A. Inflammation and cancer: back to Virchow? Lancet 2001, 357, 539-545.

215. Balkwill, F.; Coussens, L.M. An inflammatory link. Nature 2004, 431, 405-406.

216. Balkwill, F.; Charles, K.A.; Mantovani, A. Smoldering and polarized inflammation in the initiation and promotion of malignant disease. Cancer Cell 2005, 7, 211-217.

217. Coussens, L.M.; Werb, Z. Inflammation and cancer. Nature 2002, 420, 860-867.

218. DeClerck, Y.A.; Mercurio, A.M.; Stack, M.S.; Chapman, H.A.; Zutter, M.M.; Muschel, R.J.; Raz, A.; Matrisian, L.M.; Sloane, B.F.; Hendrix, M.J.; Coussens, L.; Padarathsingh, M. Proteases, extracellular matrix, and cancer. Am. J. Pathol. 2004, 164, 1131-1139.

219. Moss, S.F.; Blaser, M.J. Mechanisms of disease: inflammation and the origins of cancer. Review. Nature Clin. Pract. 2005, 2, 90-97.

220. De Visser, K.E.; Eichten, A.; Coussens, L.M. Paradoxical roles of the immune system during cancer development. Nat. Rev. Cancer 2006, 6, 24-37. 
221. Tlsty, T.D.; Coussens, L.M. Tumor stroma and regulation of cancer development. Annu. Rev. Pathol. Mech. Dis. 2006, 1, 119-150.

222. Lin, W.W.; Karin, M. A cytokine-mediated link between immunity, inflammation, and cancer. J. Clin. Invest. 2007, 117, 1175-1183.

223. Gregoire, M.; Lieubeau, B. The role of fibroblasts in tumor behavior. Cancer Met. Rev. 1995, 14, 339-350.

224. Bissel, M.J.; Radisky, D. Putting tumors in context. Nat. Rev. Cancer 2001, 1, 46-54.

225. Kenny, P.A.; Bissell, M.J. Tumor reversion: correction of malignant behavior by microenvironmental cues. Int. J. Cancer 2003, 107, 688-695.

226. Dranoff, G. Cytokines in cancer pathogenesis and cancer therapy. Nat. Rev. Cancer. 2004, 4, 11-22.

227. Bigg, H.F.; Wait, R.; Rowan, A.D.; Cawston, T.E. The mammalian chitinase-like lectin, YKL-40, binds specifically to type I collagen fibril formation. J. Biol. Chem. 2006, 281, 21082-21095.

228. Jacques, C.; Recklies, A.D.; Levy, A.; Berenbaum, F. HC-gp39 contributes to chondrocyte differentiation by inducing SOX9 and type II collagen expressions. Osteoarthritis Cartilage. 2007, 15, 138-146.

229. Meyer, M.F.; Kreil, G. Cells expressing the DG42 gene from early Xenopus embryos synthesize hyaluronan. Proc. Natl. Acad. Sci. USA 1996, 93, 4543-4547.

230. Semino, C.E.; Specht, C.A.; Raimondi, A.; Robbins, P.W. Homologs of the Xenopus developmental gene DG42 are present in zebrafish and mouse and are involved in the synthesis of Nod-like chitin oligosaccharides during early embryogenesis. Proc. Natl. Acad. Sci. USA 1996, 93, 4548-4553.

231. Varki, A. Does DG42 synthesize hyaluronan or chitin? A controversy about oligosaccharides in vertebrate development. Proc. Natl. Acad. Sci. USA 1996, 93, 4523-4525.

232. Toole, B.P. Hyaluronan: from extracellular glue to pericellular cue. Nat. Rev. Cancer 2004, 4, 528-539.

233. Fjeldstad, K.; Kolset, S.O. Decreasing the metastatic potential in cancers - targeting the heparan sulfate proteoglycans. Curr. Drug Targets 2005, 6, 665-682.

234. Iwata, T.; Kuwajima, M.; Sukeno, A.; Ishimaru, N.; Hayashi, Y.; Wabitsch, M.; Mizusawa, N.; Itakura, M. Yoshimoto, K. YKL-40 secreted from adipose tissue inhibits degradation of type I collagen. Biochem. Biophys. Res. Commun. 2009, 388, 511-516.

235. Locker, G.Y.; Hamilton, S.; Harris, J.; Jessup, J.M.; Kemeny, N.; MacDonald, J.S.; Somerfield, M.R.; Hayes, D.F.; Bast, R.C. ASCO 2006 update of recommendations for the use of tumor markers in gastrointestinal cancer. J. Clin. Oncol. 2006, 24, 5313-5327.

236. Hayes, D.F.; Bast, R.C.; Desch, C.E.; Fritsche, H.; Kemeny, N.E.; Jessup, J.M.; Locker, G.Y.; Macdonald, J.S.; Mennel, R.G.; Norton, L.; Ravdin, P.; Taube, S.; Winn, R.J. Tumor Marker Utility Grading System: a framework to evaluate clinical utility of tumor markers. J. Natl. Cancer Inst. 1996, 88, 1456-1466.

237. Hayes, D.F. Determination of clinical utility of tumor markers: a tumor marker utility grading system. Recent Results Cancer Res. 1998, 152, 71-85.

238. Werner, M.; Fraser, C.; Silverberg, M. Clinical utility and validation of emerging biochemical markers for mammary adenocarcinoma. Clin. Chem. 1993, 39, 2386-2396. 
239. Morrow, D.A.; de Lemos, J.A. Benchmarks for the assessment of novel cardiovascular biomarkers. Circulation 2007, 115, 949-952.

240. Freeman, W.M.; Bixler, G.V.; Brucklacher, R.M.; Lin, C.M.; Patel, K.M.; Vanguilder, H.D.; Lanoue, K.F.; Kimball, S.R.; Barber, A.J.; Antonetti, D.A.; Gardner, T.W.; Bronson, S.K. A multistep validation process of biomarkers for preclinical drug development. Pharmacogenomics J. 2009, doi:10.1038/tpj.2009.60.

(C) 2010 by the authors; licensee MDPI, Basel, Switzerland. This article is an Open Access article distributed under the terms and conditions of the Creative Commons Attribution license (http://creativecommons.org/licenses/by/3.0/). 